\title{
The application of the Modified Band Approach for the calculation of on-line photodissociation rate constants in TM5: implications for oxidative capacity
}

\author{
J. E. Williams, A. Strunk, V. Huijnen, and M. van Weele \\ KNMI, Chemistry and Climate division, De Bilt, The Netherlands \\ Correspondence to: J. E. Williams (williams@knmi.nl) \\ Received: 17 August 2011 - Published in Geosci. Model Dev. Discuss.: 16 September 2011 \\ Revised: 15 December 2011 - Accepted: 22 December 2011 - Published: 6 January 2012
}

\begin{abstract}
A flexible and explicit on-line parameterization for the calculation of tropospheric photodissociation rate constants ( $J$-values) has been integrated into the global Chemistry Transport Model TM5. Here we provide a comprehensive description of this Modified Band Approach (MBA) including details of the optimization procedure employed, the methodology applied for calculating actinic fluxes, the photochemical reaction data used for each chemical species, the aerosol climatology which is adopted and the parameterizations adopted for improving the description of scattering and absorption by clouds. The resulting $J$-values change markedly throughout the troposphere when compared to the offline approach used to date, with significant increases in the boundary layer and upper troposphere. Conversely, for the middle troposphere a reduction in the actinic flux results in a decrease in $J$-values. Integrating effects shows that application of the MBA introduces seasonal dependent differences in important trace gas oxidants. Tropospheric ozone $\left(\mathrm{O}_{3}\right)$ changes by $\pm 10 \%$ in the seasonal mean mixing ratios throughout the troposphere, especially over land. These changes and the perturbations in the photolysis rate of $\mathrm{O}_{3}$ induce changes of $\pm 15 \%$ in tropospheric $\mathrm{OH}$. In part this is due to an increase in the re-cycling efficiency of nitrogen oxides. The overall increase in northern hemispheric tropospheric ozone strengthens the oxidizing capacity of the troposphere significantly and reduces the lifetime of $\mathrm{CO}$ and $\mathrm{CH}_{4}$ by $\sim 5 \%$ and $\sim 4 \%$, respectively. Changes in the tropospheric $\mathrm{CO}$ burden, however, are limited to a few percent due to competing effects. Comparing the distribution of tropospheric ozone in the boundary layer and middle troposphere against observations in Europe shows there are improvements in the model performance during boreal winter in the Northern Hemisphere near regions affected by high
\end{abstract}

nitrogen oxide emissions. Monthly mean total columns of nitrogen dioxide and formaldehyde also compare more favorably against OMI and SCIAMACHY total column observations.

\section{Introduction}

Tropospheric composition is principally governed by photochemical reaction cycles which generate free-radical oxidants (e.g. the hydroxyl radical, $\mathrm{OH}$ ) that exhibit high chemical reactivity and, thus, determine the lifetime of harmful pollutants emitted from the Earth's surface (e.g. Lelieveld et al., 2002). Therefore the performance of any large-scale model used for studying atmospheric chemical processes is critically sensitive to the accuracy with which the intensity of photolysing light is calculated, and its subsequent variability with altitude, latitude, longitude and season.

The spherically integrated flux of photons at any point in the atmosphere is commonly known as the (spectral) actinic flux $\left(F_{\text {act. }}\right)$ and is dependent on the absorption and scattering of incident solar radiation by gaseous molecules, clouds and aerosols. The penetration depth of any given photon is determined by the incident angle at which the extra-terrestrial sunlight enters the top of the atmosphere (TOA) i.e. the solar zenith angle (SZA, $\theta$ ). The subsequent fate of the photon is determined by absorption and the extent of single and multiple scattering. Any chemical species $(i)$ which exhibits photochemical activity has a characteristic wavelength $(\lambda)$ dependent absorption cross section $\left(\sigma_{i}\right)$. The efficiency at which that chemical species is photochemically destroyed is determined by its quantum yield $\left(\phi_{i}\right)$, which may range from $0-1$ for any particular $\lambda$. Both of these molecular properties

Published by Copernicus Publications on behalf of the European Geosciences Union. 
may be dependent on the pressure and temperature of the surrounding air. The resulting photodissociation rate constants $\left(J_{i}\right)$ are calculated by integrating the product of $F_{\text {act }}$, $\sigma_{i}$ and $\phi_{i}$ across all wavelengths for each respective chemical species that is photochemically active, as described in Eq. (1):

$J_{i}=\int \sigma_{i}(\lambda) \phi_{i}(\lambda) F_{\text {act }}(\lambda) d \lambda$

The calculation of the photodissociation rate constants $J_{i}$ (hereafter referred to as $J$-values) requires the application of a spectral grid upon which the necessary photolytic input parameters $\left(F_{\text {act }}, \sigma_{i}, \phi_{i}\right)$ are binned. It has previously been shown that such spectral grids need to have a resolution of $\sim 1 \mathrm{~nm}$ around $\lambda=300 \mathrm{~nm}$ and contain a minimum of 100 individual spectral bins in order to provide an accurate description of tropospheric $J$-values (Madronich and Weller, 1990). Moreover, the speed and accuracy with which $F_{\text {act }}$ is calculated is dependent on the number of "streams" (scattering directions) adopted for determining the solution to the radiative transfer equation, which commonly ranges from 2 to 32 streams subject to the particular application. In general $J$-values typically increase with respect to height due to the reduction in the total integrated optical depth (OD) (lower pressure, less aerosols and clouds). The calculation of $J$-values can be prohibitively expensive in large-scale atmospheric models which need to be run over decadal timescales at high resolution, necessitating the use of either efficient parameterizations or offline look-up tables (e.g. Law and Pyle, 1993; Brasseur et al., 1998). Most large-scale global 3-D Chemistry Transport Models (CTMs) used for tropospheric studies adopted offline approaches until around a decade ago. More recently the significant increase in computing resources has allowed on-line schemes to be implemented in order to improve model performance (e.g. Voulgarakis et al., 2009). One example of such an on-line approach is the Fast Tropospheric-Ultraviolet-Visible (Fast TUV) method which uses a spectral grid containing 17 wavelength bins in conjunction with an 8-stream radiative transfer solver, where the application of pre-calculated correction factors is needed to maintain accuracy (Tie et al., 2003). Another example of an efficient on-line scheme is the Fast-J method of Wild et al. (2000). Such on-line approaches have been shown to allow a better description of the influence of clouds and aerosols on tropospheric $J$-values (e.g. Liu et al., 2006).

In this paper we provide a comprehensive description of the implementation of the on-line photolysis scheme developed by Williams et al. (2006). This scheme is flexible as it avoids the use of implicit parameterizations and has been tailored and optimized for use in tropospheric CTMs and regional air-quality models. In Sect. 2 we briefly describe the implementation of the approach in the 3-D global CTM TM5-chem-v3.0 (Huijnen et al., 2010a), give details of the most recent absorption cross sections ( $\sigma$-values) and quantum yields ( $\phi$-values) selected for each photo-active species included in the chemical scheme, outline the modifications which have been made in order to optimize the calculations for the troposphere and give a brief description of the model set-up. In Sect. 3 we compare the $J$-values calculated with the on-line scheme against $J$-values calculated with the offline parameterization currently employed in TM5-chemv3.0 (hereafter referred to as TM5) based on the Band Approach (BA) developed by Landgraf and Crutzen (1998) and expanded according to Krol and van Weele (1997). In Sect. 4 we show the resulting perturbations in the seasonal distributions of dominant trace gases and the $\mathrm{OH}$ radical and examine the annual chemical budget terms to quantify how the on-line scheme alters the dominant chemical cycles important for the troposphere. Both model versions are compared to a set of benchmark observations that was also used in Huijnen et al. (2010a). In Sect. 5. we discuss the implications of applying the new approach in TM5 for the oxidizing capacity of the troposphere and finally, in Sect. 6, we provide an overall summary of the new TM5 model version with on-line photolysis.

\section{On-line model set-up}

\subsection{The Modified Band Approach}

The method of calculating tropospheric $J$-values on-line is based on the Modified Band Approach (MBA) developed for stratospheric CTMs and Chemistry-Climate Models (CCMs) and has been comprehensively described in Williams et al. (2006), where a full error analysis of the modified approach is also provided. The MBA is an updated version of the BA originally developed by Landgraf and Crutzen (1998). To date the BA has been used for calculating tropospheric $J$-values in a number of large-scale CTMs and CCMs (e.g. von Kuhlmann et al., 2003; Jöckel et al., 2006; Huijnen et al., 2010a). One major advantage of the MBA over the BA is the on-line radiative transfer calculation using the absorption and scattering components introduced by gases, aerosols and clouds at each specific model level (Williams et al., 2006). For computational efficiency the BA typically requires the use of off-line look-up tables containing pre-calculated scaling ratios $\left(\delta_{i}\right)$ (see below) using a standard atmosphere, where the ratios are subsequently indexed with respect to temperature, pressure and total optical depth. The explicit nature of the MBA increases the flexibility of the approach compared to the BA in terms of updating molecular absorption properties ( $\sigma$-values; $\phi$-values) and the addition of new $J$-values into CTMs. The parameterizations in the BA for the effect of clouds, overhead ozone and surface albedo (Krol and van Weele, 1997) are also no longer used. Other improvements pertain to instances of large SZA, where additional constraints and spectral band limits are applied (see below). 
The spectral grid applied in the MBA is a truncated version of the grid defined in Brühl and Crutzen (1988) for the $\lambda$ range of $202-695 \mathrm{~nm}$. It contains 122 individual spectral bins of varying resolution (from $0.2 \mathrm{~nm}$ at $\lambda=300 \mathrm{~nm}$ to $5 \mathrm{~nm}$ at $\lambda=600 \mathrm{~nm}$ ). Following the approach outlined in Landgraf and Crutzen (1998) these spectral bins are subsequently grouped into 7 separate absorption band intervals for use in the approximation, thus: $202.0-241.0 \mathrm{~nm}, 241.0-289.9 \mathrm{~nm}$, $289.9-305.5 \mathrm{~nm}, 305.5-313.5 \mathrm{~nm}, 313.5-337.5 \mathrm{~nm}, 337.5-$ $422.5 \mathrm{~nm}$ and $422.5-695 \mathrm{~nm}$. These band intervals were chosen in order to minimize errors in the final $J$-values (Landgraf and Crutzen, 1998). The spectral range of the grid is constrained by the $\sigma$ values of ozone $\left(\mathrm{O}_{3}\right)$. Due to the efficient screening of photons at $\lambda<202 \mathrm{~nm}$ by gaseous oxygen $\left(\mathrm{O}_{2}\right)$ and $\mathrm{O}_{3}$, the absorption band in the MBA associated with the far UV spectral region (179-202 nm) can be ignored during the calculation of tropospheric $J$-values.

A second set of band intervals are used between SZA values of $\theta=71-85^{\circ}$ (hereafter referred to as the large- $\theta$ wavelength grid intervals), which have been shown to improve the accuracy of the approximation at low sun (Williams et al., 2006). The large- $\theta$ wavelength grid intervals account for the diminishing incident radiation in the UV entering the troposphere whenever the overhead slant column (path length) is large, i.e. at large SZA. The effects of refraction due to spherical geometry for $\mathrm{SZA}>85^{\circ}$ are not included here. Such geometrical effects are considered not to be important for global tropospheric chemistry compared to e.g. polar stratospheric chemistry.

The MBA calculates a full solution of the radiative transfer equation to derive $F_{\text {act }}$ for a single pre-defined wavelength bin that is contained within each of the 7 absorption band intervals. Using the asymmetry factors the Mie-scattering components introduced by both clouds and aerosols are accounted for in the calculation of $F_{\text {act }}$ using plane-parallel geometry. For $\theta<71^{\circ}$ the central wavelengths of these bins are $205.1 \mathrm{~nm}, 287.9 \mathrm{~nm}, 302.0 \mathrm{~nm}, 309.0 \mathrm{~nm}, 320.0 \mathrm{~nm}$, $370.0 \mathrm{~nm}$ and $580.0 \mathrm{~nm}$, respectively. For $\theta>71^{\circ}$ the large $-\theta$ wavelength grid intervals are used, with the central wavelengths of the bins being $209.4 \mathrm{~nm}, 287.9 \mathrm{~nm}, 302.0 \mathrm{~nm}$, $311.0 \mathrm{~nm}, 326.5 \mathrm{~nm}, 385.0 \mathrm{~nm}$ and $610.0 \mathrm{~nm}$, respectively. Following the original $\mathrm{BA}$ the resulting $F_{\text {act }}$ values are then used to produce the corresponding $\delta_{i}$ ratios by scaling with the spectral actinic flux in a purely absorbing (non-scattering) atmosphere $\left(F_{\text {abs }}\right)$, according to Eq. (2).

$\delta_{i}=\frac{F_{\mathrm{act}}\left(\lambda_{i}\right)}{F_{\mathrm{abs}}\left(\lambda_{i}\right)}$

The use of $\delta_{i}$ is a necessary approximation to allow the application of the MBA in global CTMs, where the direct calculation of $F_{\text {act }}$ for each spectral bin is still too computationally expensive. At large $\mathrm{SZA}, \delta_{i}$ values which are calculated higher up in the column are adopted for the lowest layers of the troposphere, where there is still adequate illumination (see Table 4 in Williams et al., 2006 for details of the reasoning behind this approach and the subsequent thresholds applied for calculating $F_{\text {abs }}$ ). This constraint ensures that erroneously high $\delta_{i}$ values are not used for instances of low sun, where the direct component of the incident flux becomes close to zero. The $J$-value calculated for a purely absorbing atmosphere $\left(J_{\text {abs }}\right)$ is scaled using the respective $\delta_{i}$ values and the contributions are summed across all band intervals for the derivation of the final $J$-value $\left(J_{\mathrm{x}}\right)$ according to Eq. (3):

$J_{x}=\sum_{i} J_{i}^{\mathrm{abs}} \delta_{i}$

\subsection{Calculation of the actinic flux $\left(F_{\text {act. }}\right)$}

The vertical slant column (i.e. the distance traveled through the atmosphere by any photon) at each model level is calculated using the method outlined in Madronich (1987). For the Rayleigh scattering component due to air, the crosssections are calculated following the empirical approach of Nicolet (1984). The scattering optical depth of liquid clouds is calculated using the parameterization of Slingo (1989), where the parameterization of the relation between effective radius of cloud droplets $\left(r_{\text {eff }}\right)$ and liquid water content (LWC) follows McFarlane et al. (1992), according to Eq. (4):

$r_{\text {eff }}=11 \times \mathrm{LWC}+4$

Here $r_{\mathrm{eff}}$ is in $\mu \mathrm{m}$ and the LWC is in $\mathrm{gm}^{-3}$, where the LWC is calculated using the ECMWF ERA-interim meteorological data which is updated every $3 \mathrm{~h}$. Constraints are placed on the minimum $r_{\text {eff }}$ of $4 \mu \mathrm{m}$ over land and on the maximum $r_{\text {eff }}$ of $12 \mu \mathrm{m}$ for a non-precipitating cloud. Examples of the instantaneous distribution of the partial LWP (Liquid Water Path, i.e. the LWC vertically integrated over the model layer) and $r_{\text {eff }}$ are given at $945 \mathrm{hPa}$ and $500 \mathrm{hPa}$ in Figs. S1a and b in the Supplement, respectively. In general, smaller cloud droplets exist over the land whereas larger cloud droplets exist over the ocean, especially in the tropics between $30^{\circ} \mathrm{S}-30^{\circ} \mathrm{N}$. This introduces significantly different scattering and absorption components for any given location. The parameterization provides values of $r_{\text {eff }}$, total LWP, and cloud OD (equal to $1.5 \times \mathrm{LWP} / r_{\text {eff }}$ ) that are within the range derived for a variety of different marine stratocumulus clouds over the ocean from e.g. the Advanced Very High Resolution Radiometer (AVHRR) instrument (Szczodrak et al., 2001). The cloud fraction in each grid cell is subsequently used to weight the scattering that occurs in a typical model grid cell during the calculation of $F_{\text {act }}$ (see below). For the contribution to the scattering OD from cirrus particles, the parameterization of $\mathrm{Fu}$ (1996) is adopted, which is consistent with the parameterization used for calculating the $r_{\text {eff }}$ of cirrus particles in TM5 (Huijnen et al., 2010a). This provides values of scattering OD for cirrus particles which are within the range observed during a host of different measurement campaigns (Heymsfield et al., 2005). 
For aerosols in the boundary layer, either a marine or rural aerosol type is prescribed according to whether the land fraction is $>30 \%$ of the total grid cell area, where the optical properties for each type are taken as defined in the parameterization of Shettle and Fenn (1979). Here the influence of relative humidity on aerosol size via deliquescence (and thus affecting the amount of Mie-scattering by aerosols) is accounted for, although no interaction with cloud liquid droplets (scavenging and washout) is included. Therefore, in the version of TM5 used in this study the aerosol profile is fixed throughout the simulations i.e. the aerosols are not transported. At higher altitudes (above the boundary layer) and at the poles a free tropospheric aerosol type is prescribed throughout the column which exhibits less absorption and higher scattering. However, a major advantage of the explicit nature of the MBA is that there is also the possibility of including varying aerosol optical properties from realistic aerosol distributions e.g. as provided on-line in TM5 by the M7 aerosol scheme (Vignati et al., 2004; Aan de Brugh et al., 2010) or observational data sets provided off-line such as those released due to biomass burning activity (e.g. van der Werf et al., 2006). This coupling of realistic and varying aerosol effects in the photolysis rate calculations will be an important next step in the TM5 model development.

The extra-terrestrial solar spectrum applied at the TOA was taken from the composite assembled by Dobber et al. (2008) and supplemented with that of Neckel and Labs (1984) for $\lambda>550 \mathrm{~nm}$. The resulting composite was then interpolated onto the working spectral grid of Brühl and Crutzen (1988). No solar cycle is currently imposed on the TOA flux although variations in the Earth-Sun distance are taken into account.

The calculation of the SZA in the MBA has been modified to account for the length of the chemical time-step employed in TM5, which is typically set at $15 \mathrm{~min}$ (Huijnen et al., 2010a). For this an average SZA is calculated using 1/6, $3 / 6$ and $5 / 6$ of the chemical time-step across the minimum, mean and maximum longitudinal limits for the centre latitude of each model grid cell. For the BA the SZA is calculated at the start of each chemical time step for grid co-ordinates located in the centre of each model grid cell. This leads to differences in the SZA applied at each chemical time-step between both of the approaches, with those in the MBA typically varying between $1-3^{\circ}$ compared to the corresponding values in the BA, depending on latitude and season. Maximal effects occur at high latitudes, resulting in more grid cells being photolytically active with the MBA near the poles during their respective winters, although the corresponding $J$-values are rather small. The differences between the SZA calculated for the BA and MBA for the first hour of 1 January and the 1 July are shown in Fig. S2 of the Supplement.

For the calculation of $F_{\text {act }}$ values we use the 2-stream radiative transfer solver of Zdunkowski et al. (1980) known as the Practical Improved Flux Method (PIFM). This approach uses the integrated absorption of photons $\left(\mathrm{O}_{2}, \mathrm{O}_{3}\right.$, aerosols and clouds) and scattering (gaseous molecules, clouds and aerosols) in the overhead column at each respective model layer. Partial cloud coverage is accounted for during the calculation of $F_{\text {act }}$ using the random overlap approach of Geleyn and Hollingsworth (1979) using the respective cloud fractions. No spherical effects due to refraction are accounted for at large SZA. In TM5 the surface albedo for each grid cell is a composite of the various land-types contained within each grid cell calculated according to Eq. (5):

$$
\begin{aligned}
& \text { Albedo }=\text { Fract. }(\text { ocean }) \times 0.05+\text { Fract. }(\text { sea_ice }) \times \\
& 0.7+\text { Fract }(\text { bare_soil }) \times 0.05+\text { Fract. }(\text { desert }) \times 0.1+ \\
& \text { Fract. }(\text { vegetation }) \times 0.01+\text { Fract. }(\text { snow }) \times 0.7
\end{aligned}
$$

The values for the spectrally independent albedo for the different surface types are chosen from the database of Koelemeijer et al. (2003). The fraction of sea-ice per grid cell originates from the ECMWF ERA-interim meteorological data. Seasonal composites of the surface albedo for December-January-February (DJF) and JuneJuly-August (JJA) are shown in Fig. S3 in the Supplement, where significant variability exists on land masses in the Northern Hemisphere (NH) associated with snow cover during DJF.

\subsection{Absorption cross section and quantum yields}

The characteristic absorption cross sections ( $\sigma$-values) and quantum yields ( $\phi$-values) used for each respective species have been updated and are given in Table 1 as taken from the latest recommendations of either Atkinson et al. (2006) or Sander et al. (2011). In total 17 individual $J$-values are calculated every model time-step throughout the atmospheric column. Compared with TM5 (Huijnen et al., 2010a) there is the addition of the $J$-value of $\mathrm{O}_{2}\left(J_{\mathrm{O}_{2}}\right)$ between 202$240 \mathrm{~nm}$. Although the penetration depth of photons into the troposphere is rather limited in this UV range, Prather (2009) has recently demonstrated that this photolytic process is important for $\mathrm{O}_{3}$ production in the upper troposphere (UT) of the tropics and suggests it should therefore be included in tropospheric CTMs. Equations (6)-(8) show the additional sequence of reactions which is included to describe this process:

$\mathrm{O}_{2}+h v \rightarrow \mathrm{O}\left({ }^{3} \mathrm{P}\right)+\mathrm{O}\left({ }^{3} \mathrm{P}\right)$

$\mathrm{O}\left({ }^{3} \mathrm{P}\right)+\mathrm{O}_{2} \rightarrow \mathrm{O}_{3}$

$\mathrm{O}\left({ }^{3} \mathrm{P}\right)+\mathrm{O}_{3} \rightarrow 2 \mathrm{O}_{2}$

The competition for the $\mathrm{O}\left({ }^{3} \mathrm{P}\right)$ radical by both $\mathrm{NO}$ and $\mathrm{NO}_{2}$ is assumed to be insignificant due to the dominance of molecular $\mathrm{O}_{2}$ and $\mathrm{O}_{3}$ between 50-100 hPa.

For optimization purposes the number of spectral parameters declared for each particular species is reduced to avoid redundancy with respect to memory allocation (cf. Table 1). 
Table 1. Details of the photodissociation reactions calculated in TM5 with the modified band approach (MBA). The number of spectral bins needed for deriving each respective $J$-value as defined by the availability of $\sigma$-and $\phi$-values are given, where the size of the original spectral grid of Brühl and Crutzen (1988) is 142 individual spectral bins.

\begin{tabular}{llrl}
\hline $\begin{array}{l}\text { Photochemical } \\
\text { reaction }\end{array}$ & $\begin{array}{l}\text { Spectral range } \\
\text { of absorption }\end{array}$ & $\begin{array}{r}\text { Spectral } \\
\text { Bins }\end{array}$ & Reference \\
\hline $\mathrm{O}_{3}+h v \rightarrow \mathrm{O}\left({ }^{1} \mathrm{D}\right)$ & $202-695$ & 122 & Sander et al. (2011); Matsumi et al. (2002) \\
$\mathrm{NO}_{2}+h v \rightarrow \mathrm{NO}+\mathrm{O}_{3}$ & $240.9-662.5$ & 89 & Sander et al. (2011) \\
$\mathrm{H}_{2} \mathrm{O}_{2}+h v \rightarrow 2 \mathrm{OH}$ & $202-350$ & 65 & Sander et al. (2011) \\
$\mathrm{HNO}_{3}+h v \rightarrow \mathrm{OH}+\mathrm{NO}_{2}$ & $202-350$ & 65 & Sander et al. (2011) \\
$\mathrm{HNO}_{4}+h v \rightarrow \mathrm{HO}_{2}+\mathrm{NO}_{2}$ & $202-350$ & 65 & Sander et al. (2011) \\
$\mathrm{N}_{2} \mathrm{O}_{5}+h v \rightarrow \mathrm{NO}_{3}+\mathrm{NO}_{2}$ & $202-420$ & 72 & Sander et al. (2011) \\
$\mathrm{CH}_{2} \mathrm{O}+h v \rightarrow \mathrm{CO}$ & $226-375$ & 111 & Atkinson et al. (2006) \\
$\mathrm{CH}_{2} \mathrm{O}+h v \rightarrow \mathrm{CO}+2 \mathrm{HO}_{2}$ & $226-375$ & 111 & Atkinson et al. (2006) \\
$\mathrm{CH}_{3} \mathrm{OOH}+h v \rightarrow \mathrm{CH}_{2} \mathrm{O}+\mathrm{HO}_{2}+\mathrm{OH}$ & $202-405$ & 69 & Sander et al. (2011) \\
$\mathrm{NO}_{3}+h v \rightarrow \mathrm{NO}+\mathrm{O}_{3}$ & $403-691$ & 62 & Sander et al. (2011) \\
$\mathrm{NO}_{3}+h v \rightarrow \mathrm{NO}$ & $403-691$ & 62 & Sander et al. (2011) \\
$\mathrm{PAN}+h v \rightarrow \mathrm{C}_{2} \mathrm{O}_{3}+\mathrm{NO}_{2}$ & $202-350$ & 65 & Sander et al. (2011) \\
$\mathrm{ORGNTR}^{2} h v \rightarrow \mathrm{HO}_{2}+\mathrm{NO}_{2}^{\mathrm{a}}$ & $202-320$ & 60 & Atkinson et al. (2006) \\
$\mathrm{ALD}_{2}+h v \rightarrow \mathrm{CH}_{2} \mathrm{O}_{2}+\mathrm{XO}_{2}+\mathrm{CO}+2 \mathrm{HO}_{2}^{\mathrm{b}}$ & $202-350$ & 65 & Atkinson et al. (2006) \\
$\mathrm{CH}_{3} \mathrm{C}(\mathrm{O}) \mathrm{CHO} \rightarrow \mathrm{C}_{2} \mathrm{O}_{3}+\mathrm{HO}_{2}+\mathrm{CO}$ & $202-493$ & 91 & Sander et al. (2011) \\
$\mathrm{ROOH}+h v \rightarrow \mathrm{OH}^{\mathrm{c}}$ & $202-365$ & 69 & Atkinson et al. (2006) \\
$\mathrm{O}_{2} \rightarrow 2 \mathrm{O}\left({ }^{3} \mathrm{P}\right)$ & $202-245$ & 17 & Sander et al. (2011) \\
\hline
\end{tabular}

Other details: ${ }^{a}$ Average of $\sigma$-values for $1-\mathrm{C}_{4} \mathrm{H}_{9} \mathrm{ONO}_{2}$ and 2- $\mathrm{C}_{4} \mathrm{H}_{9} \mathrm{ONO}_{2}$ are used, ${ }^{\text {b }}$ Average of $\sigma$-values for $\mathrm{CH}_{3} \mathrm{CHO}$ and $\mathrm{C}_{2} \mathrm{H}_{5} \mathrm{CHO}$ are used, ${ }^{\mathrm{c}}$ The $J$-value for $\mathrm{ROOH}$ is set equal to the $J$-value of $\mathrm{CH}_{3} \mathrm{OOH}$ due to the lack of data regarding its $\sigma$-values.

In order to limit expensive interpolation steps being performed online, both the temperature dependent $\sigma$ - and $\phi$ values are stored in a look-up table that is indexed between $200-350^{\circ} \mathrm{K}$ at intervals of $5^{\circ} \mathrm{K}$. Tests have been performed with a chemical box-model to ensure that this indexing resolution does not lead to any appreciable degradation in the resulting $J$-values. One exception is for the $J$-value of methylglyoxal ( $\left.J_{\mathrm{MGLY}}\right)$, where the temperature and pressure dependent $\phi$-values are calculated online using the parameterization given in Sander et al. (2011).

\subsection{TM5 experimental set-up}

In this section we provide a brief description of the model set-up adopted for evaluating the performance of the MBA when applied in TM5. The TM5 model has recently been comprehensively described and evaluated against a variety of different measurements (Huijnen et al., 2010a). We perform simulations using 34 vertical layers at a horizontal resolution of $3^{\circ} \times 2^{\circ}$ and drive the CTM with ECMWF meteorological fields taken from the ERA-interim re-analysis (Dee et al., 2011). For this study we choose the simulation year of 2006 , identical to that chosen in Huijnen et al. (2010a). Stratospheric ozone is constrained by relaxation towards the sondebased climatology of Fortuin and Kelder (1998). The stratospheric $\mathrm{O}_{3}$ column is then scaled to the observed monthlymean total ozone columns, which are assimilated from a multi-sensor reanalysis dataset (van der A et al., 2010).
For the emission inventories we employ the presentday anthropogenic inventories from the RETRO project (Schultz et al., 2007) supplemented with those from the REAS inventory for the Asian region (Ohara et al., 2007). For biogenic emissions we adopt climatological values for ocean emissions from GEIA (Guenther et al., 1995) or for land emissions we use the 12-yr average from the ORCHIDEE model (Lathiére et al., 2006). Lightning $\mathrm{NO}_{\mathrm{x}}$ emissions are calculated using the parameterization of Meijer et al. (2001), where the total annual $\mathrm{NO}_{\mathrm{x}}$ emission introduced is $\sim 5.9 \mathrm{Tg} \mathrm{Nyr}^{-1}$. For the biomass burning emissions we use the Global Fire Emissions Database version 2 (GFEDv2) 8-day inventories (van der Werf et al., 2006). A spin-up period of one year is adopted using the relevant meteorology and emission inventories for 2005. One further modification compared with Huijnen et al. (2010a) is that the heterogeneous conversion of nitrogen pentoxide $\left(\mathrm{N}_{2} \mathrm{O}_{5}\right)$ into nitric acid $\left(\mathrm{HNO}_{3}\right)$ now uses the variable cloud droplet sizes calculated according to Eq. (4) rather than a fixed droplet size of $8 \mu \mathrm{m}$ as previously prescribed.

\section{Effect of the MBA on tropospheric $J$-values}

A direct comparison of $F_{\text {act }}$ values is not possible due to the highly parameterised nature of the methodology applied to create the offline look-up tables of the $\delta_{i}$ values used in the BA (i.e. the ratios of $\left.F_{\text {act }} / F_{\text {abs }}\right)$. As outlined in Krol and 

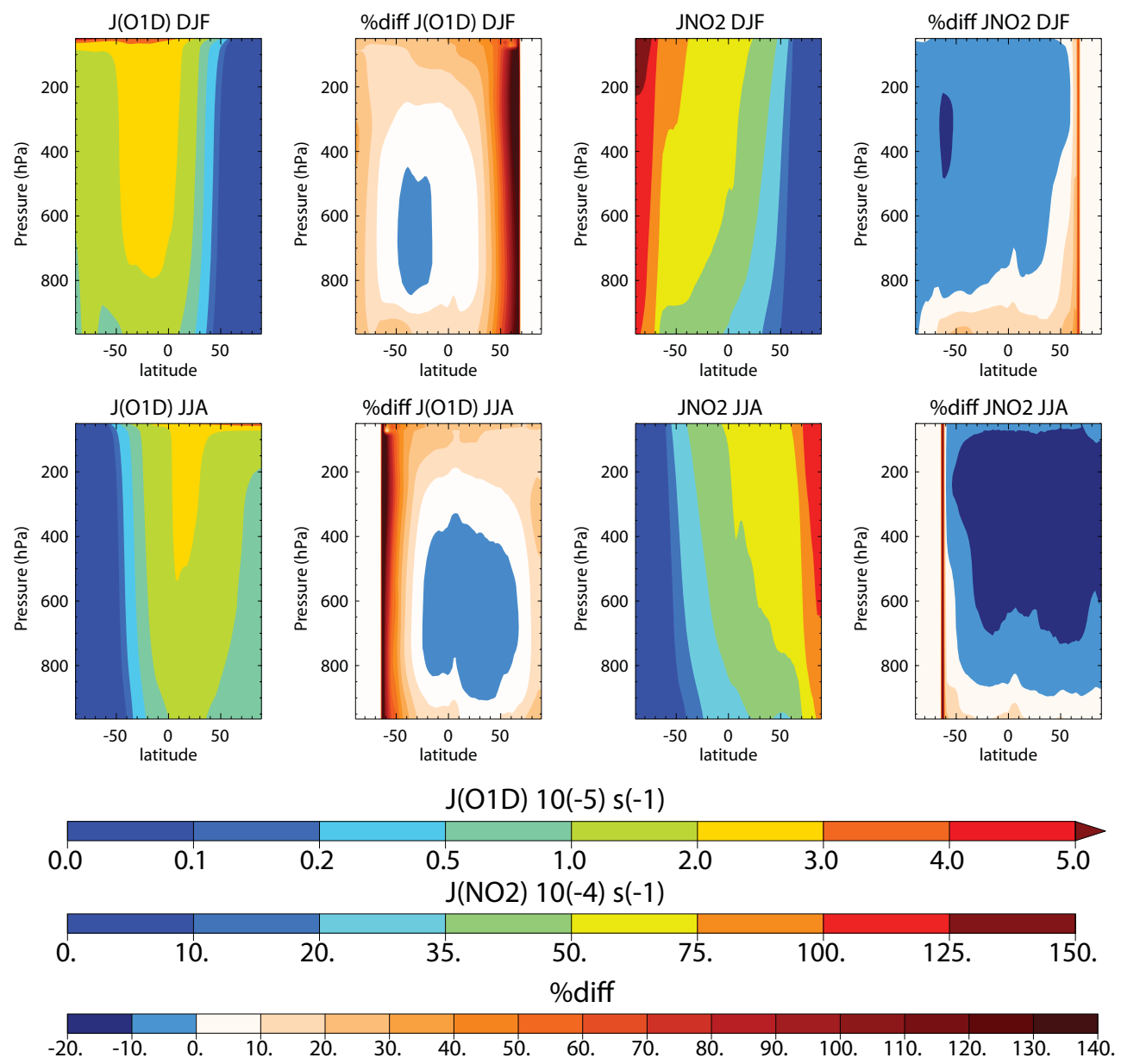

Fig. 1. The seasonal zonal mean vertical profiles of $J_{\mathrm{O}^{1} \mathrm{D}}$ and $J_{\mathrm{NO}_{2}}$ for DJF (left) and JJA (right) as calculated by the MBA. The corresponding relative differences are shown versus the $\mathrm{BA}$, where the difference is calculated as $(\mathrm{MBA}-\mathrm{BA}) / \mathrm{BA} \times 100$.

van Weele (1997), there are also parameterizations that are applied to the BA in order to provide a better description of the variability of $F_{\text {act }}$ in a non-scattering atmosphere as a function of overhead ozone and above surfaces with high albedo. A climatological aerosol scattering component is also implicitly included in these pre-calculated ratios. Therefore the analysis presented here focuses on comparisons of the final $J$-values calculated by each of the two approaches (BA and MBA) for identical atmospheres in TM5 when integrating all of the changes described above in Sect. 2. To gauge which modification introduces the most dominant effects, additional sensitivity simulations have been performed using both TM5 and a chemical box-model, with the main findings being included in the discussion below. For brevity we focus on those $J$-values which govern the oxidising capacity of the troposphere, namely the photolysis of ozone to produce excited oxygen atoms $\left(\mathrm{O}^{1} \mathrm{D}\right)\left(J_{\mathrm{O}^{1} \mathrm{D}}\right)$ and nitrogen dioxide $\left(J_{\mathrm{NO}_{2}}\right)$. Differences for those $J$-values important for the photo-dissociation of hydrogen oxide $\left(\mathrm{HO}_{\mathrm{x}}\right)$ and nitrogen oxide $\left(\mathrm{NO}_{\mathrm{x}}\right)$ reservoirs (e.g. peroxy-acetyl nitrate, PAN, and formaldehyde, $\mathrm{CH}_{2} \mathrm{O}$ ) are shown in the Supplement as Figs. S5 and S6, respectively.

Figure 1 shows the seasonal zonal variability in $J_{\mathrm{O}^{1} \mathrm{D}}$ and $J_{\mathrm{NO}_{2}}$ calculated by the MBA for DJF and JJA during 2006. Also shown are the corresponding relative differences with the $J$-values calculated by BA. As would be expected, $J_{\mathrm{O}^{1} \mathrm{D}}$ is more sensitive to the integrated $\mathrm{O}_{3}$ absorption and scattering of photons that occurs in the overhead column. Thus the magnitude of $J_{\mathrm{O}^{1} \mathrm{D}}$ decreases markedly from the UT to the lower troposphere (LT). In contrast, the atmosphere is rather transparent for radiation with wavelength $>350 \mathrm{~nm}$ resulting in $J_{\mathrm{NO}_{2}}$, whose $\phi$-values result in the most important spectral region being between $380-400 \mathrm{~nm}$, being rather homogeneous with altitude and principally governed by the incident SZA (due to the amount of scattering) and the length of the day. Analysing the corresponding difference plots shows that the MBA introduces differences in both $J_{\mathrm{O}^{1} \mathrm{D}}$ and $J_{\mathrm{NO}_{2}}$ of the order of $\pm 20 \%$, although the vertical distribution of these differences is markedly different. For $J_{\mathrm{O}^{1} \mathrm{D}}$ the differences exhibit a strong latitudinal dependency for both 
seasons, where maximal relative increases occur at high latitudes. For the middle troposphere (MT) these differences range between $\pm 10 \%$, with decreases in the tropics. For the UT there is a latitudinally independent increase in $J_{\mathrm{O}^{1} \mathrm{D}}$ of between $\sim 20-30 \%$. For $J_{\mathrm{NO}_{2}}$ increases occur in the LT whilst decreases occur in the MT and UT across all latitudes, with those for JJA being larger. The differences are related to both the updated absorption parameters and variability in the incident $F_{\text {act }}$. For instance, chemical box modeling studies have shown that updating the $\sigma$ - and $\phi$-values for $\mathrm{NO}_{2}$ from those applied in the BA leads to an increase in $J_{\mathrm{NO}_{2}}$ of between $\sim 5-20 \%$ depending on latitude and season (Williams and van Noije, 2008). Therefore the decreases shown for $J_{\mathrm{NO}_{2}}$ in the MT and UT are due to a reduction in the $F_{\text {act }}$ values calculated between both approaches when applying all the modifications documented in Sect 2. The increases in the LT for both $J$-values are due modifications in the scattering component resulting from the different aerosol climatology used in MBA and the new parameterizations for the description of the optical properties of aerosols and clouds.

To quantify the effect of aerosol OD on tropospheric $J$ values in the MBA a sensitivity test was performed where the aerosol OD was set to zero with the scattering and absorption due to clouds still active. The effect on $J$-values in the MBA is limited to the order of $\sim 0.5 \%$ (not shown), which is an order of magnitude lower than that found by Martin et al. (2003). Examining the aerosol OD around $320 \mathrm{~nm}$ calculated by the approach of Shettle and Fenn (1979) shows that the total aerosol optical depth defined for the generic aerosol types are rather conservative. This is lower than the sulphate contribution calculated in many other large-scale global models (e.g. Schulz et al., 2006), but the influence of aerosol types such as secondary organic aerosol (SOA), black carbon and nitrate are not included. In the BA an aerosol OD value of 0.38 at $320 \mathrm{~nm}$ is implicitly applied, which uses the profiles given in Elterman (1968).

For clouds the OD introduced by the Slingo (1989) parameterization is much larger than the aerosol OD, therefore perturbing $J$-values to a much greater extent. Performing a sensitivity study using a clear-sky atmosphere shows that both $J$-values decrease (increase) in the boundary layer (free troposphere; FT) by the order of $\sim 10-30 \%(\sim 2-20 \%)$ due to the presence of clouds, which agrees with previous findings in the literature (e.g. van Weele and Duynkerke, 1993; Tie et al., 2003; Krol and van Weele, 1997; Voulgarakis et al., 2009). Larger (smaller) $r_{\text {eff }}$ in the MBA result in a lower (higher) albedo in the BA than the MBA for a given liquid water content and a given flux of incident radiation at the cloud-top via the Twomey effect (Twomey, 1977). Moreover, at high latitudes $\left(>70^{\circ} \mathrm{N} / \mathrm{S}\right)$ the reduced aerosol OD, the application of the large- $\theta$ wavelength intervals, the differences in the SZA values, and the application of the threshold limits for calculating $\delta_{i}$ results in large relative increases for $J_{\mathrm{O}^{1} \mathrm{D}}$ of between $\sim 100-200 \%$ during polar winter, although $J_{\mathrm{O}^{1} \mathrm{D}}$ values are small under such scenarios.
Figure 2 shows the seasonal surface means and corresponding percentage differences for each $J$-value for seasons DJF and JJA. There is a sharp cut-off in $J$-values around $\sim 70^{\circ} \mathrm{N}\left(\sim 70^{\circ} \mathrm{S}\right)$ in polar winter due to the lack of incident radiation in this season. The relative differences introduced by the MBA are larger for $J_{\mathrm{O}^{1} \mathrm{D}}$ than for $J_{\mathrm{NO}_{2}}$ due to a larger sensitivity of UV actinic fluxes in the troposphere to, e.g. the slant column than those in the visible. For latitudes where a large SZA occurs throughout a significant portion of the day (e.g. Europe during DJF) relative differences exceeding $100 \%$ occur for surface $J_{\mathrm{O}^{1} \mathrm{D}}$ values. The effects of the relatively minor differences in SZA between MBA and BA can be seen in the surface differences for $J_{\mathrm{NO}_{2}}$ at high latitudes where more grid cells become photolytically active. The influence of the variability in scattering due to cloudiness, aerosols and surface albedo between different regions becomes apparent in the geographical distribution of the differences. The current application of the aerosol scheme prescribes rural aerosol over all land types. More sophisticated aerosol schemes such as M7 (Vignati et al., 2004) will be coupled to the MBA in future studies, which is likely to moderate surface $J$-values due to the inclusion of both more scattering and more absorption (black carbon) compared to the climatology of Shettle and Fenn (1979).

In order to quantify the impact of introducing the parameterization for variable cloud droplet sizes on tropospheric $J$-values, a sensitivity simulation was performed using the MBA where the $r_{\text {eff }}$ was fixed at $8 \mu \mathrm{m}$ (i.e. the default value adopted in TM5 in Huijnen et al., 2010a). Over large land masses differences of $\pm 2 \%$ occur whereas near regions of strong convective activity, such as near tropical storm tracks that contain high cloud OD values, decreases of $\sim 15-25 \%$ occur (not shown).

The influence of changing the TOA solar spectrum was quantified by replacing the solar spectrum of Dobber et al. (2008) with that based on measurements by the SOLar SPECtrum spectrometer (SOLSPEC) on the ATLAS-3 mission (Thuillier et al., 2003), which is similar to that used in the construction of the offline look-up tables used by the BA. The main differences are that the spectrum of Dobber et al. (2008) is provided at a higher resolution and with a higher radiometric accuracy, which is especially important for the UV region where the width of the spectral bins used by the MBA are $\sim 0.2 \mathrm{~nm}$. The application of the TOA spectrum of Thuiller et al. (2003) decreases $J_{\mathrm{O}^{1} \mathrm{D}}$ by $\sim 2-7 \%$, with the largest differences occurring away from the tropics $\left(>50^{\circ} \mathrm{S} / 50^{\circ} \mathrm{N}\right)$. For $J_{\mathrm{NO}_{2}}$ there are only small increases of a few percent homogeneously distributed across all latitudes due to the net change in TOA flux between spectra being different for the ultraviolet and visible spectral regions (not shown). The integrated difference over the spectral range $\lambda=200-600 \mathrm{~nm}$ is $\sim 2.2 \%$ in the TOA flux, with the more recent Dobber et al. (2008) spectra being the brightest.

Figure 3 includes direct comparisons of the monthly mean variability for selected grid cells to show the seasonal impact 

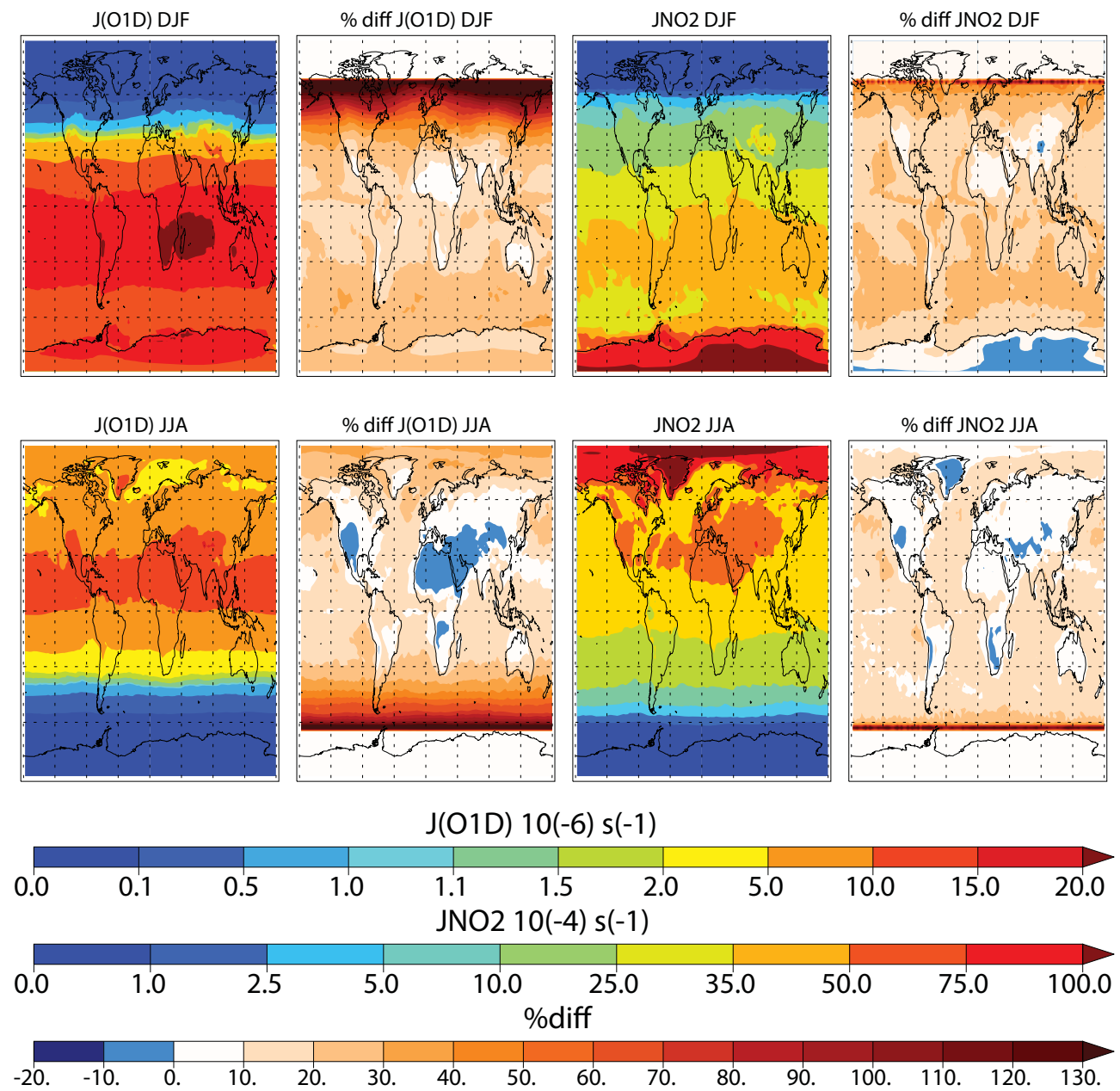

Fig. 2. The same as Fig. 1 but for the seasonal surface means for $J_{\mathrm{O}^{1} \mathrm{D}}$ (top) and $J_{\mathrm{NO}_{2}}$ (bottom) for DJF (left) and JJA (right).

on $J_{\mathrm{O}^{1} \mathrm{D}}$ and $J_{\mathrm{NO}_{2}}$ at the surface during 2006. Strong seasonal cycles are evident in the means and the largest absolute differences are associated with the high values which occur during JJA. Comparing latitudinal differences between the $\mathrm{BA}$ and the MBA shows that the correspondence is best in the mid-latitudes around $40^{\circ} \mathrm{N}$. This is surprising as the $F_{\text {act }}$ values used in the BA are calculated using Air Force Geophysics Laboratory (AFGL) tropical profiles for 21 March (Anderson et al., 1986) using a fixed surface albedo of 0.05 , with further modifications made according the Krol and van Weele (1997). Therefore it is clear that there is some cancellation of effects between the different approaches. For the region lying in the tropics no seasonal cycle in the differences between $J$-values is found. The new $J$-values from MBA exceed the original BA $J$-values by $\sim 20 \%$ throughout the year, with the $\sim 80 \%$ of photochemical oxidation occurring at these latitudes.

Large scale CTMs typically have problems in capturing the small-scale variability associated with $J$-values due to the coarse horizontal resolutions employed, the staggered update frequency of the meteorological parameters and the lack of accurate input data for e.g. aerosols. Comparing $J$-values in the extra-tropics shows that the $J$-values simulated in TM5 by the MBA are similar to those that have been measured during various field campaigns. For instance, measurements taken in June at Ann Arbor, Michigan, US $\left(42.2^{\circ} \mathrm{N}, 83.8^{\circ} \mathrm{W}\right.$, $300 \mathrm{~m}$ ), during the International Photolysis Frequency Measurement and Modeling Intercomparison (IPMMI) at Boulder, Colorado, US $\left(39.6^{\circ} \mathrm{N}, 105.1^{\circ} \mathrm{W}, 1800 \mathrm{~m}\right)$ and in August during the POPCORN campaign at Pennewitt, Germany $\left(53.8^{\circ} \mathrm{N}, 11.8^{\circ} \mathrm{E}\right)$ indicate that the daily means of $J_{\mathrm{O}^{1} \mathrm{D}}$ at the surface are of the order of $\sim 1.2-1.5 \times 10^{-5} \mathrm{~s}^{-1}$ (Dickerson et al., 1982; Hofzumahaus et al., 2004; Kraus and Hofzumahaus, 1998), although the absolute values depend on cloud cover and SZA. The corresponding measurements for $J_{\mathrm{NO}_{2}}$ indicate daily means of the order of $4-6 \times 10^{-3} \mathrm{~s}^{-1}$, with the magnitude being rather insensitive to altitude (Dickerson et al., 1982; Kraus and Hofzumahaus, 1998). Comparing the monthly mean values shown in Fig. 3 for latitudes $40-50^{\circ} \mathrm{N}$ show that both surface $J$-values are close to the observed 

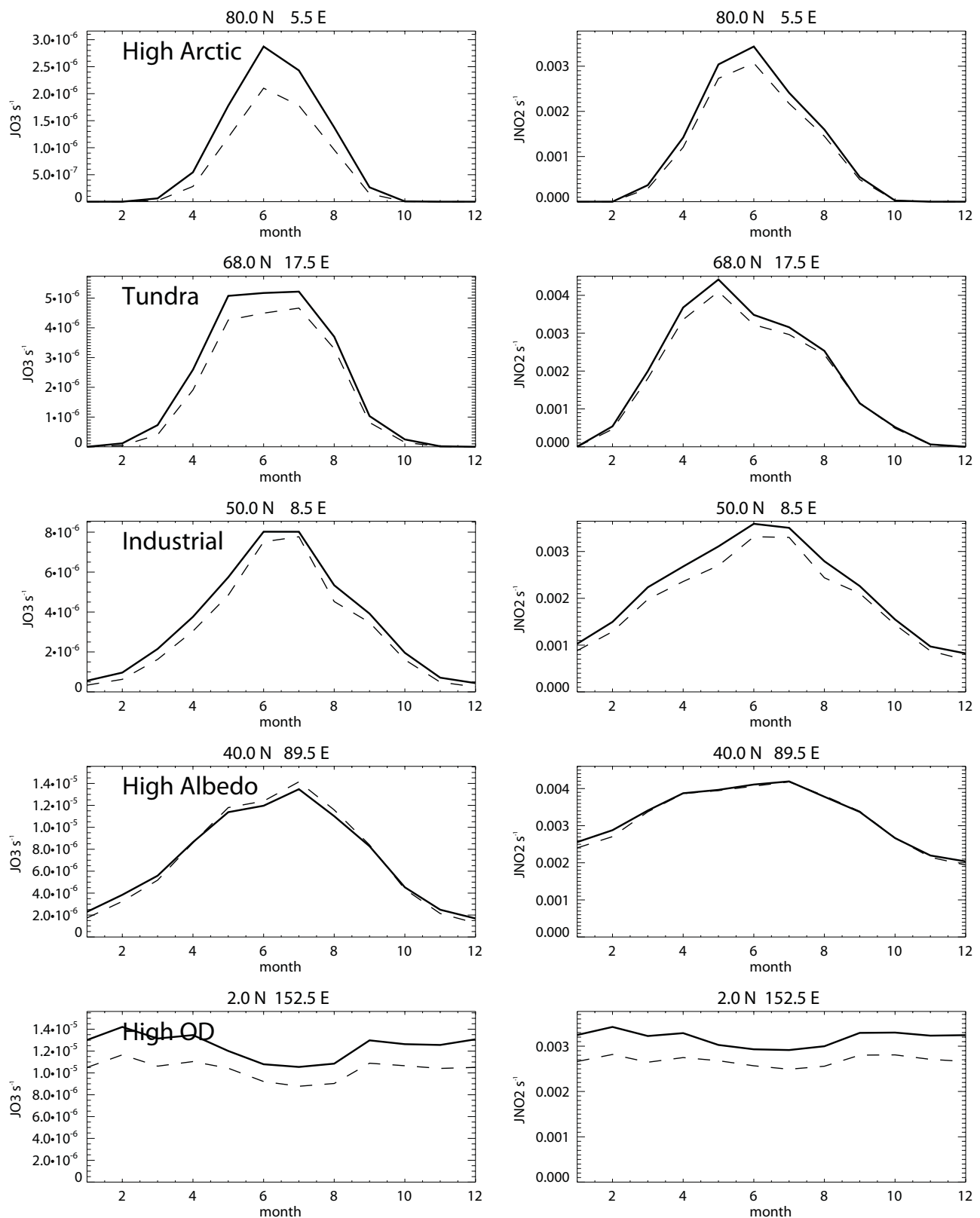

Fig. 3. The monthly mean variability of (left) $J_{\mathrm{O}^{1} \mathrm{D}}$ and (right) $J_{\mathrm{NO}_{2}}$ at the surface for different locations in the $\mathrm{NH}$ as calculated by the BA $(-)$ and MBA (---). The type of grid cell at which the comparisons are made is shown in the inset of each figure.

daily means, although $J_{\mathrm{NO}_{2}}$ calculated by the MBA may be on the low side, which would suppress $\mathrm{O}_{3}$ formation in the CTM. Cloud effects (e.g. extent of coverage) could most probably explain the somewhat lower $J$-values calculated using the MBA.

For instances where the water vapour mixing ratio is similar, the relationship between the surface concentration of $\mathrm{OH}$ and $J_{\mathrm{O}^{1} \mathrm{D}}$ has been shown to be remarkably robust over a wide range of $\mathrm{NO}_{\mathrm{x}}$ environments (Ehhalt and Rohrer, 2000). When comparing monthly mean values obtained at the Meteorological Observatory Hohenpeissenburg
(MOHp) $\left(47.2^{\circ} \mathrm{N}, 11.0^{\circ} \mathrm{E}\right)$ between the years 1999 to 2003 , Rohrer and Berresheim (2006) (hereafter RB06) have shown that the relationship is essentially linear, with a high correlation co-efficient of 0.985 over the $J_{\mathrm{O}^{1} \mathrm{D}}$ range of 0 $8 \times 10^{-6} \mathrm{~s}^{-1}$. Figure 4 shows the corresponding values at the surface layer for the BA (blue) and MBA (yellow) simulations for the period 2004 to 2007, along with the approximate relationship shown in RB06 (red). The model values are taken from the model grid cell at the surface which contains the location of MOHp. For the other years the TM5 simulations are conducted using the relevant ERA-interim 


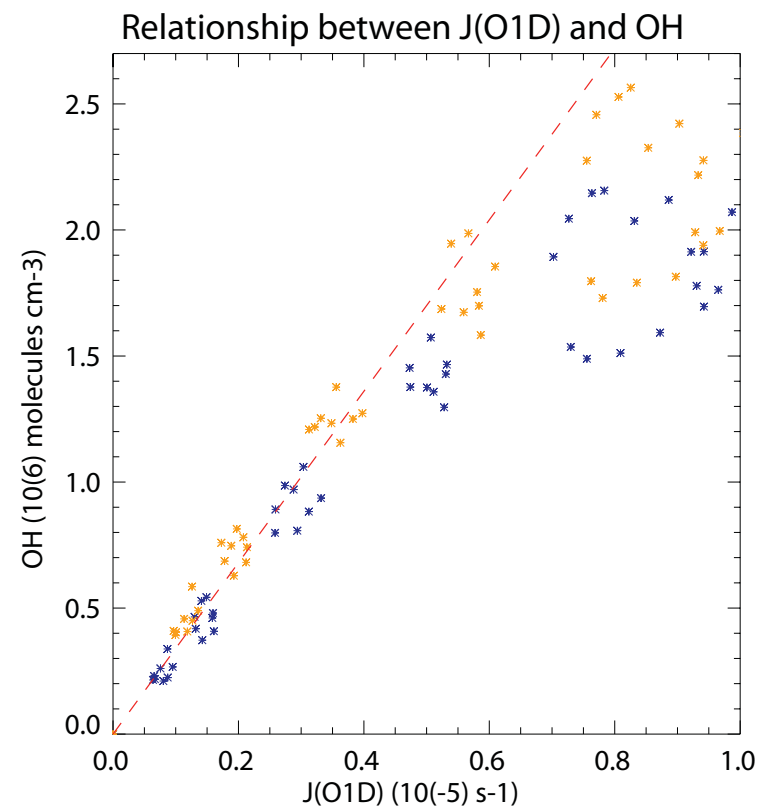

Fig. 4. The relationship between monthly mean $J_{\mathrm{O}^{1} \mathrm{D}}$ (per sec) and the surface concentration of $\mathrm{OH}$ (in molecules $\mathrm{cm}^{-3}$ ) for the years 2004 through to 2007 for the BA (blue) and MBA (yellow). The red line represents the approximate fit to measurements taken at Hohenpeissenberg (Rohrer and Berresheim, 2006).

meteorology and boundary conditions, where the emission estimates are updated to account for the inter-annual variability in biomass burning (GFEDv2) and the estimated growth in anthropogenic emissions from the REAS region $\left(10^{\circ} \mathrm{S}-\right.$ $\left.50^{\circ} \mathrm{N}, 60-150^{\circ} \mathrm{E}\right)$. It can be seen that a similar relationship between both parameters also exists in TM5, with correlation co-efficients in the range of 0.98 . Performing a linear fit over the range $0-8 \times 10^{-6} \mathrm{~s}^{-1}$ results in gradients of 2.72 (BA) and 2.92 (MBA) versus 3.4 for the approximate relationship as derived by RB06. Thus the application of the MBA shows a better agreement with the relationship derived from the measurements. One noticeable difference between the model values and the measurements are the high $J_{\mathrm{O}^{1} \mathrm{D}}$ values of between $8-10 \times 10^{-6} \mathrm{~s}^{-1}$ that are not observed at MOHp. For these high $J_{\mathrm{O}^{1} \mathrm{D}}$ averages the linear relationship with $\mathrm{OH}$ concentration appears to break down. This occurs mainly during boreal summer, i.e. for relatively small SZA. A possible cause is therefore the treatment of (uncertain) model cloud parameters in the (M)BA two-stream radiative transfer scheme. Actinic fluxes are most sensitive to cloud assumptions, e.g. on cloud overlap, for small SZA. Homogeneous thin clouds for small SZA would lead to enhancements of the below-cloud actinic flux instead of reductions (van Weele and Duynkerke, 1993; Madronich, 1987).

\section{Effect of the MBA on the distribution of global trace gases}

Figure $5 \mathrm{a}$ and $\mathrm{b}$ shows the zonally averaged global vertical distributions of $\mathrm{O}_{3}, \mathrm{NO}_{\mathrm{x}}$, carbon monoxide $(\mathrm{CO})$ and $\mathrm{OH}$ using the MBA for the seasons DJF and JJA, respectively. The right panels in Fig. 5a and $\mathrm{b}$ show the relative changes with respect to the application of the BA in TM5. The corresponding changes at the surface for both seasons are shown in Fig. $\mathrm{S} 4$ of the Supplement. Note that $\mathrm{NO}_{\mathrm{x}}$ is being defined as a composite of $\mathrm{NO}, \mathrm{NO}_{2}, \mathrm{NO}_{3}, \mathrm{~N}_{2} \mathrm{O}_{5}$ and $\mathrm{HNO}_{4}$. This $\mathrm{NO}_{\mathrm{x}}$ composite is the $\mathrm{NO}_{\mathrm{x}}$ species that is transported in TM5 and shown here (Huijnen et al., 2010a). The perturbation in $\mathrm{NO}_{\mathrm{x}}$ introduced by the MBA is mainly determined by the changes in the photolysis rates of two most important $\mathrm{NO}_{\mathrm{x}}$ reservoirs (PAN, $J_{\mathrm{PAN}}$, and nitric acid $\left.\left(\mathrm{HNO}_{3}\right), J_{\mathrm{HNO}_{3}}\right)$ as shown in Fig. S7 of the Supplement.

\subsection{Tropospheric ozone $\left(\mathrm{O}_{3}\right)$}

For tropospheric $\mathrm{O}_{3}$ the largest seasonal increases of $\sim 5$ $15 \%$ occur in the $\mathrm{NH}$ during DJF. There are corresponding decreases in the $\mathrm{SH}$ of a few percent due to a significant reduction in the long-range transport of PAN into more remote regions ( $\sim 20-30 \%$, see Fig. S7 in the Supplement) and faster photolytic destruction in the LT. There are also significant increases in the tropical UT of between $\sim 2-20 \%$ associated with the introduction of $J_{\mathrm{O}_{2}}$. The seasonal pattern in the latitudinal differences can be attributed to the variability and intensity of available sunlight. The largest increases in surface $\mathrm{O}_{3}(\sim 25-50 \%$ or $2-15 \mathrm{ppb}$, see Fig. S4 in the Supplement) occur during DJF near regions that exhibit high $\mathrm{NO}_{\mathrm{x}}$ emission sources i.e. Europe, Eastern US and China. For JJA the corresponding increases in surface $\mathrm{O}_{3}$ are more muted ( $\sim 5-15 \%$ or $2-5 \mathrm{ppb})$. The corresponding reductions in surface $\mathrm{NO}_{\mathrm{x}}$ and increase in $\mathrm{O}_{3}$ loss via photolysis show that increases in surface $\mathrm{O}_{3}$ are due to an enhancement in the $\mathrm{NO}_{\mathrm{x}}$ re-cycling efficiency for the MBA and, thus, an increase in the net $\mathrm{O}_{3}$ production per molecule of $\mathrm{NO}_{\mathrm{x}}$ emitted (see Table 2 below). For more remote regions changes in surface $\mathrm{O}_{3}$ are limited to a few percent.

The changes in the annual chemical budget terms for tropospheric $\mathrm{O}_{3}$ are given in Table 2. In addition to the globally integrated chemical budget, the analysis is also partitioned into components for the SH extra-tropics (90$\left.30^{\circ} \mathrm{S}\right)$, tropics $\left(30^{\circ} \mathrm{S}-30^{\circ} \mathrm{N}\right)$, and $\mathrm{NH}$ extra-tropics $\left(30^{\circ} \mathrm{N}-\right.$ $\left.90^{\circ} \mathrm{N}\right)$. The tropopause height used for the calculations follows the definition given in Stevenson et al. (2006), where a threshold of $150 \mathrm{ppb}$ for $\mathrm{O}_{3}$ mixing ratios is used. Identical tropopause heights are adopted for both simulations as calculated in the BA simulation in order to fix the total mass of tropospheric air. The stronger photochemical activity due to higher $J$-values causes an increase in both the global in-situ production and destruction terms for tropospheric $\mathrm{O}_{3}$ by $\sim 5 \%$ and $\sim 4 \%$, respectively. The 
(a)
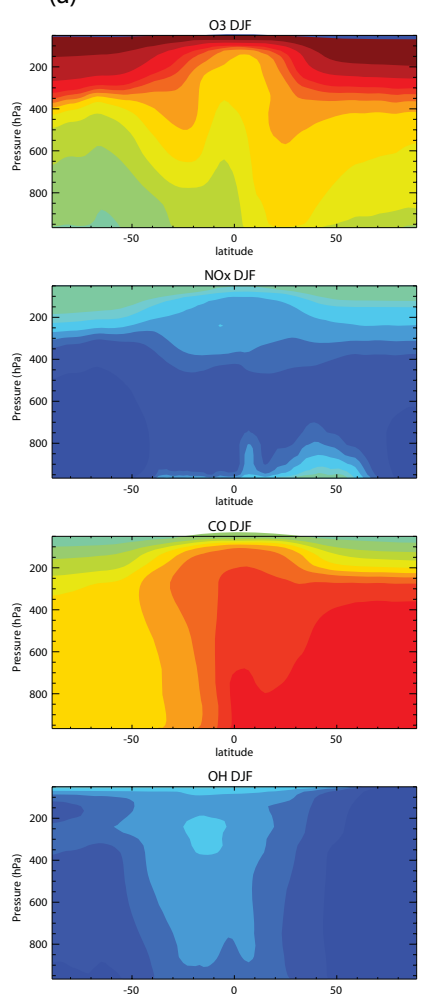

batiude $\quad{ }^{50} \operatorname{pptv}^{*} 10$ or ppbv
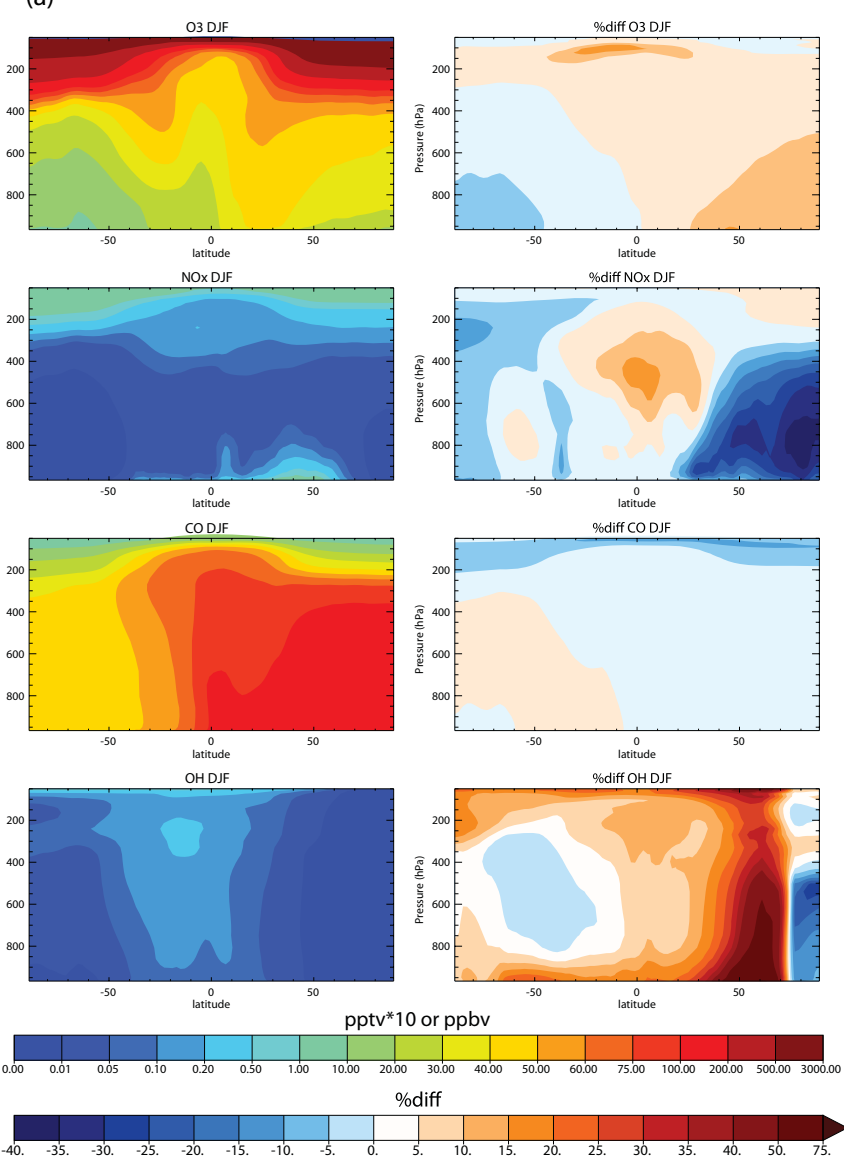

latitude

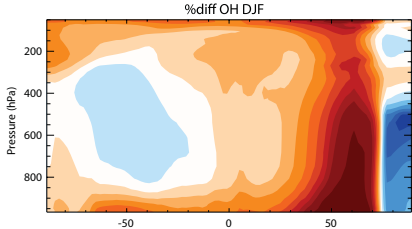

(b)
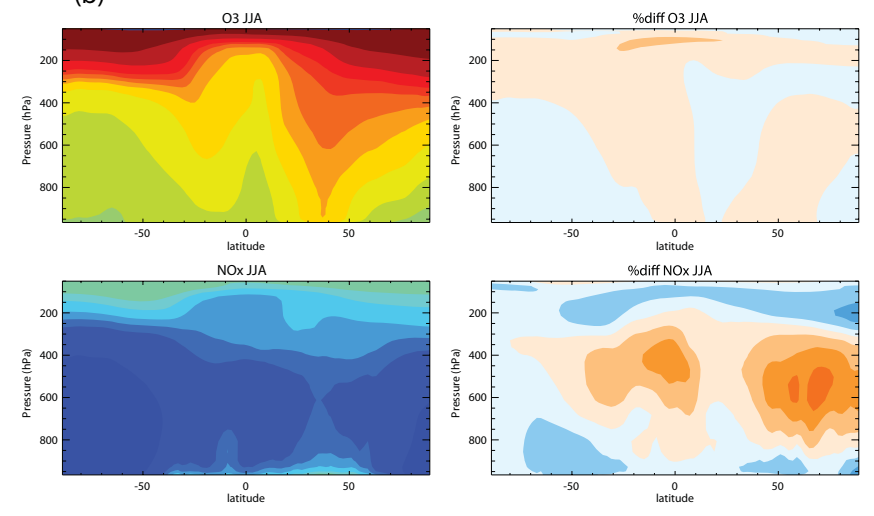

со נر
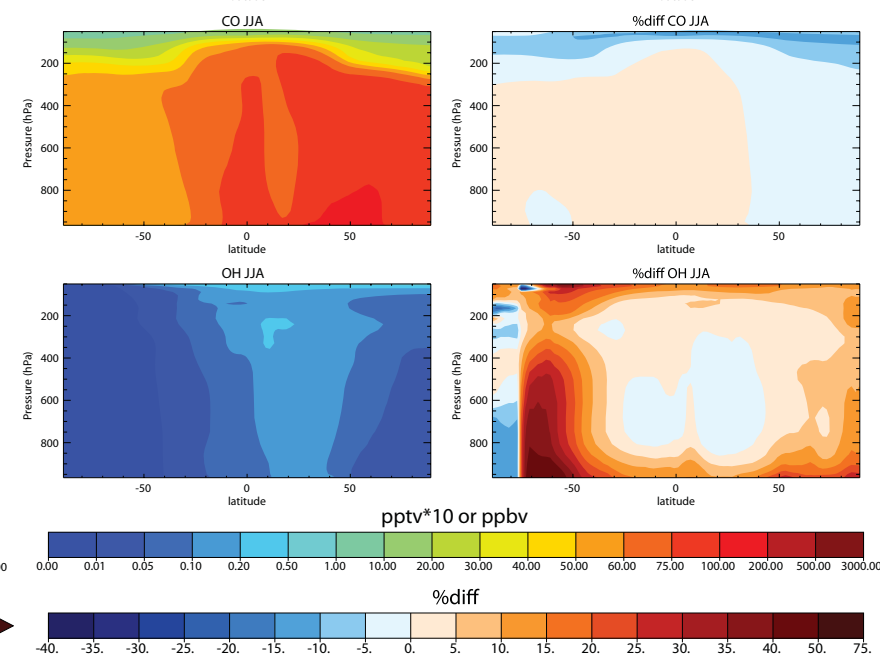

Fig. 5. (a) The zonally averaged distribution of $\mathrm{O}_{3}, \mathrm{NO}_{\mathrm{x}}, \mathrm{CO}$ and $\mathrm{OH}$ for season DJF during 2006 as calculated by the Modified Band Approach. The mixing ratio of $\mathrm{OH}$ is scaled up for clarity. The right panels show the corresponding relative differences against the Band Approach, where the differences is calculated as $(2 \times(\mathrm{MBA}-\mathrm{BA}) /(\mathrm{MBA}-\mathrm{BA})) \times 100$. (b) As for (a) except for season JJA.

Table 2. The tropospheric chemical budget for $\mathrm{O}_{3}$ given in $\mathrm{Tg} \mathrm{O}_{3} \mathrm{yr}^{-1}$ during 2006 when applying the MBA. The relative percentage differences are also shown $((\mathrm{MBA}-\mathrm{BA}) / \mathrm{BA} \times 100)$. The contribution to each term from the SH extra-tropics/tropics/NH extra-tropics $($ defined as $90-30^{\circ} \mathrm{S} / 30^{\circ} \mathrm{S}-30^{\circ} \mathrm{N} / 30-90^{\circ} \mathrm{N}$ ) are provided.

\begin{tabular}{lllll}
\hline Budget Term & Global & SH & Tropics & NH \\
\hline Net Stratospheric Exchange & $274(-9.6 \%)$ & & & \\
Trop. Chem. Prod. & $4729(+5.0 \%)$ & $288(+1.0 \%)$ & $3413(+4.6 \%)$ & $1028(+7.0 \%)$ \\
Trop. Chem. Loss & $4147(+4.2 \%)$ & $314(+2.9 \%)$ & $3155(+4.0 \%)$ & $679(+5.8 \%)$ \\
Trop. Burden & $320(+1.3 \%)$ & $59(-1.6 \%)$ & $172(+2.4 \%)$ & $89(+1.1 \%)$ \\
Deposition & $863(+3.3 \%)$ & $83(-1.2 \%)$ & $448(+3.7 \%)$ & $332(+5.1 \%)$ \\
Lifetime (days) & $23.4(-3.0 \%)$ & & & \\
\hline
\end{tabular}

regional budgets show that the increase in chemical activity is higher in the extra-tropical $\mathrm{NH}$, where $\sim 44 \%$ of the total global $\mathrm{NO}_{\mathrm{x}}$ emissions are released. The contribution by $J_{\mathrm{O}_{2}}$ to the total tropospheric production term is limited to $\sim 0.7 \%$, although for the tropical UT the contribution is more significant (not shown). When comparing the stratosphere-troposphere exchange (STE) calculated for the
BA ( $~ 300 \mathrm{Tg} \mathrm{O}_{3} \mathrm{yr}^{-1}$ ) against the value given in Huijnen et al. (2010a) of $421 \mathrm{Tg} \mathrm{O}_{3} \mathrm{yr}^{-1}$ reveals it is significantly smaller due to the use of the ERA-interim re-analysis meteorology, where it has recently been shown to reduce transport from the stratosphere into the troposphere when compared to the corresponding operational analyses (Monge-Sanz et al., 2007). However, performing comparisons of seasonal 
(a)


MOZAIC O, profiles, DJF 2006

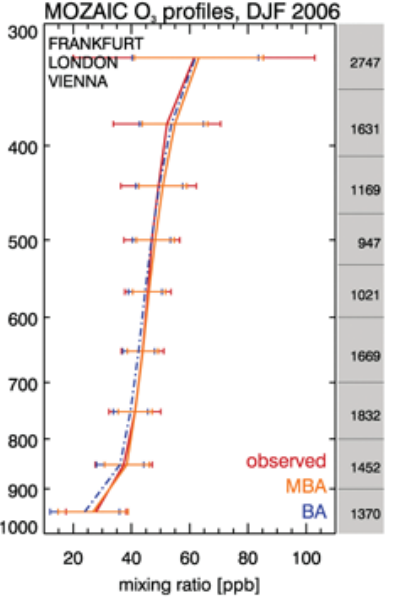

MOZAIC O, profiles, DJF 2006

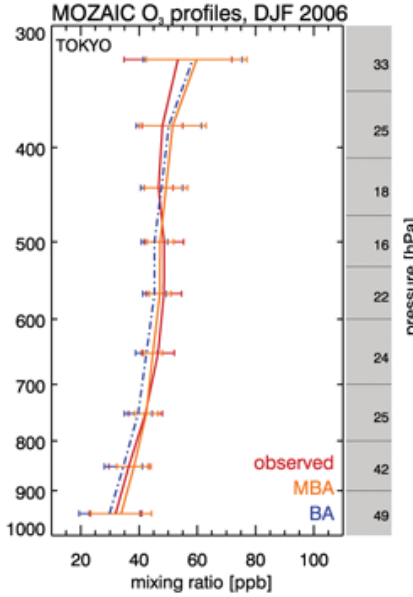

(b)
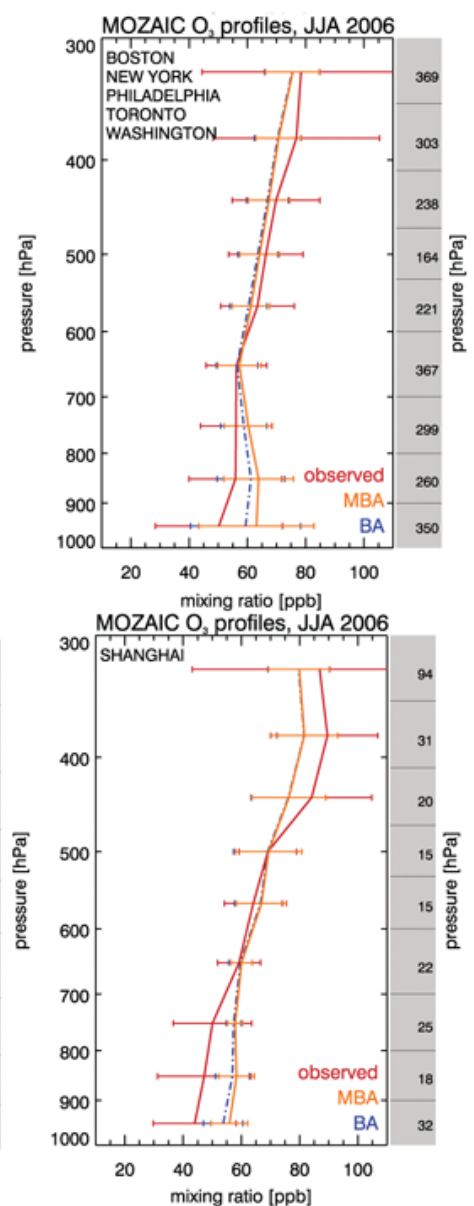

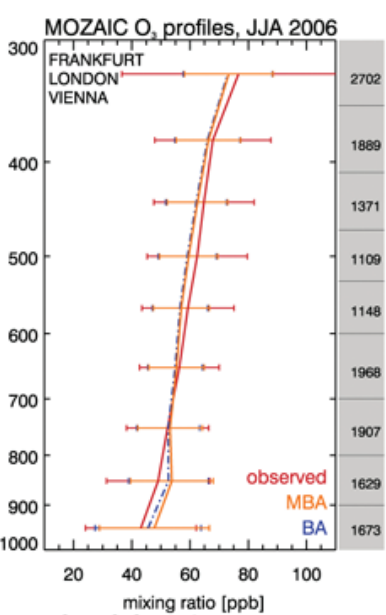

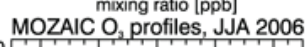

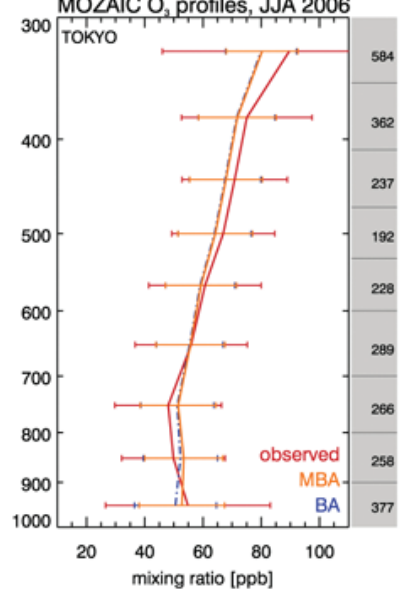

Fig. 6. (a) Comparisons of the vertical distributions of tropospheric ozone measured during take-off and landing as part of MOZAIC for season DJF during 2006. Regional comparisons are shown for (from top left to bottom right) the Eastern US (Atlanta; $33.6^{\circ} \mathrm{N}, 84.4^{\circ} \mathrm{W}$; Boston; $42.4^{\circ} \mathrm{N}, 71.0^{\circ} \mathrm{W}$; Charlotte; $35.2^{\circ} \mathrm{N}, 80.9^{\circ} \mathrm{W}$; New York; 40.6 $6^{\circ} \mathrm{N}, 73.8^{\circ} \mathrm{W}$; and Washington; $\left.39.9^{\circ} \mathrm{N}, 77.5^{\circ} \mathrm{W}\right)$, Europe (Frankfurt; $50.0^{\circ} \mathrm{N}, 8.5^{\circ} \mathrm{E}$; London; $51.2^{\circ} \mathrm{N}, 0.2^{\circ} \mathrm{W}$; Vienna; $48.1^{\circ} \mathrm{N}, 16.6^{\circ} \mathrm{E}$ ), China (Shanghai; $\left.31.2^{\circ} \mathrm{N}, 121.3^{\circ} \mathrm{E}\right)$ and Japan $\left(\mathrm{Tokyo} ; 35.8^{\circ} \mathrm{N}\right.$, $\left.140.4^{\circ} \mathrm{E}\right)$. The number of measurements included in each vertical bin is shown in the grey bar on the right of each plot. (b) As for (a) except for season JJA during 2006.

$\mathrm{O}_{3}$ composites from TM5 using the BA against ozonesondes at high latitudes (not shown) indicates that TM5 has low mixing ratios of $\mathrm{O}_{3}$ in the lower stratosphere when using ERA-interim meteorology and nudging the stratospheric $\mathrm{O}_{3}$ distribution towards the ozone climatology above $90 \mathrm{hpa}$. When compared against the STE calculated in a recent multimodel comparison of $556 \pm 154 \mathrm{Tg} \mathrm{O}_{3} \mathrm{yr}^{-1}$ for the year 2000 (Stevenson et al., 2006), the STE value calculated here for the $\mathrm{BA}$ is $\sim 50 \%$ lower, falling outside the $1-\sigma$ deviance of the ensemble mean. The application of the MBA further reduces the STE value by nearly $\sim 10 \%$ due to the increase in $\mathrm{O}_{3}$ in the UT and lower stratosphere in the tropics (not shown), which reduces the concentration gradient and therefore the net mixing of $\mathrm{O}_{3}$ into the troposphere. For the chemical production and destruction terms the agreement with the multimodel ensemble mean is somewhat better, where the values given in Table 2 lie within the 1- $\sigma$ deviance of the ensemble mean. Moreover, in that both terms increase compared to the BA shows that the chemical activity of the model is improving when considering other CTMs. Similar improvements occur for the atmospheric lifetime of tropospheric $\mathrm{O}_{3}$ and the tropospheric $\mathrm{O}_{3}$ burden, which exhibit a decrease of $\sim 3 \%$ and an increase of $\sim 1 \%$, respectively, again indicating faster recycling of $\mathrm{NO}_{\mathrm{x}}$.

Figure 6a and $\mathrm{b}$ shows seasonal comparisons of tropospheric $\mathrm{O}_{3}$ profiles for DJF and JJA for both BA and MBA together with $\mathrm{O}_{3}$ profile observations taken over various airports as part of the MOZAIC measurement program (Measurement of Ozone and Water Vapour by Airbus In-Service Aircraft; e.g. Marenco et al., 1998; Thouret et al., 1998). The high sampling rate and the location of the airports make such comparisons more suitable for this study rather than 

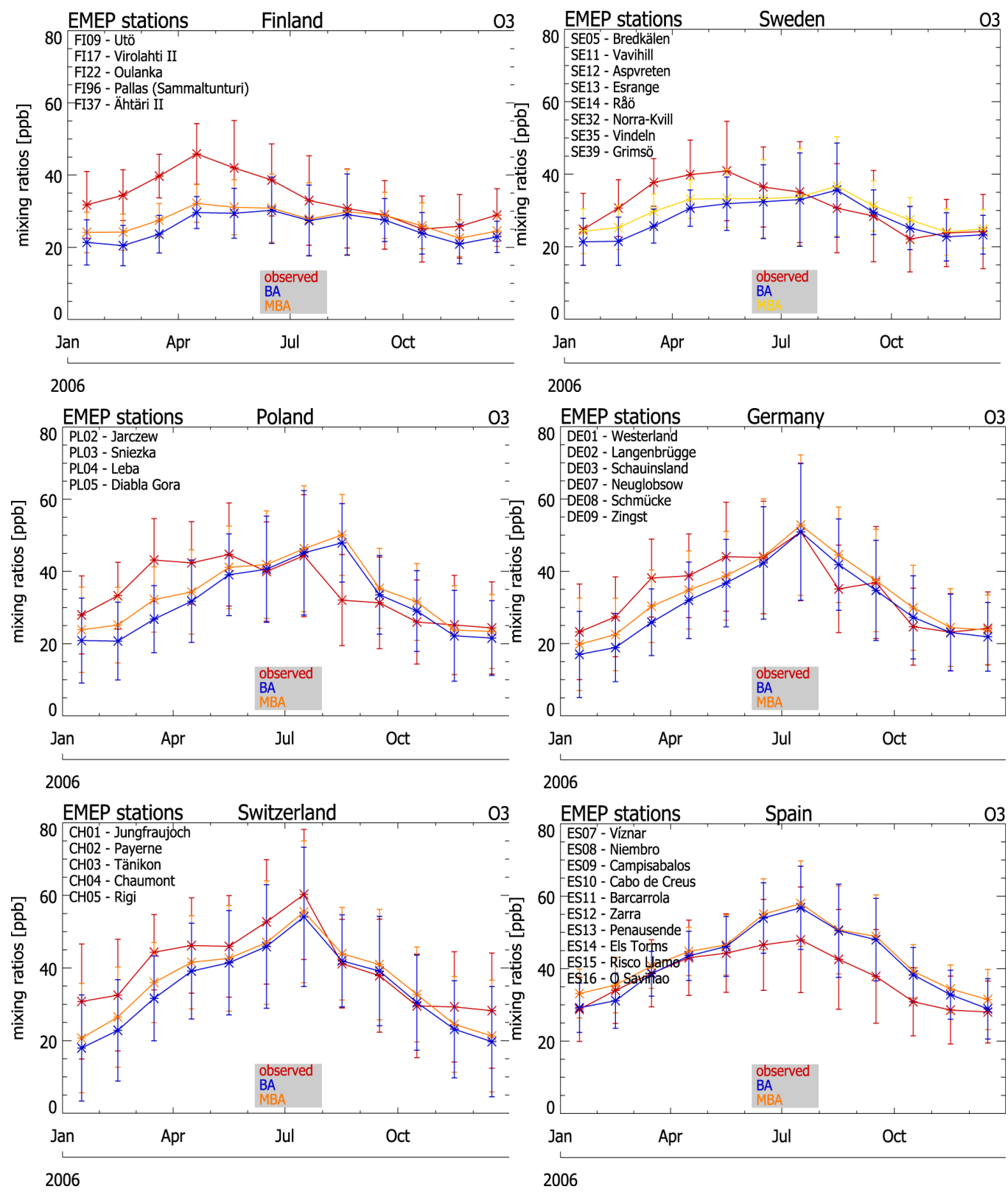

2006

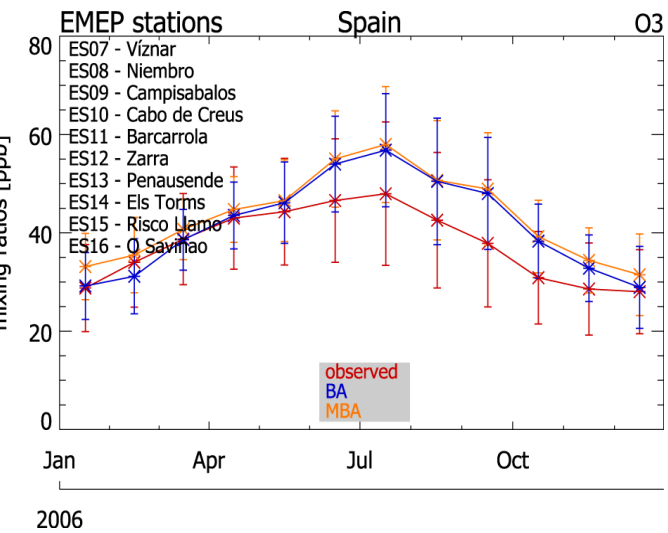

Fig. 7. Comparisons of the seasonal cycle of surface $\mathrm{O}_{3}$ during 2006 with EMEP composites for selected countries in Europe. The error bars represent the 1- $\sigma$ spread in the model mean values. The names of the EMEP stations used for each composite are shown top left, with the choice being constrained by data availability.

using composites of ozonesondes measurements, which typically have a much lower sampling rate and are launched at sites situated at more remote locations. In order to assemble the model profiles we use model output sampled every $3 \mathrm{~h}$ throughout the year and apply spatio-temporal interpolation to match the location of the observations. In general the comparisons show that differences in the FT are rather small, although for JJA the MBA improves the agreement with the seasonal MOZAIC composite. In the LT (boundary layer) the increases in tropospheric $\mathrm{O}_{3}$ due to the MBA generally lead to a better correspondence with the MOZAIC profiles for both seasons, although this leads to a slight overestimation during JJA. The increases in tropospheric $\mathrm{O}_{3}$ in the MBA compared to the BA are primarily due to the enhanced chemical production term, in spite of the more efficient redistribution of $\mathrm{NO}_{\mathrm{x}}$ into the FT (where more reactive nitrogen is lofted out of the boundary layer) and the enhanced production of $\mathrm{HNO}_{3}$ (see Sect. 4.2). Compared to 

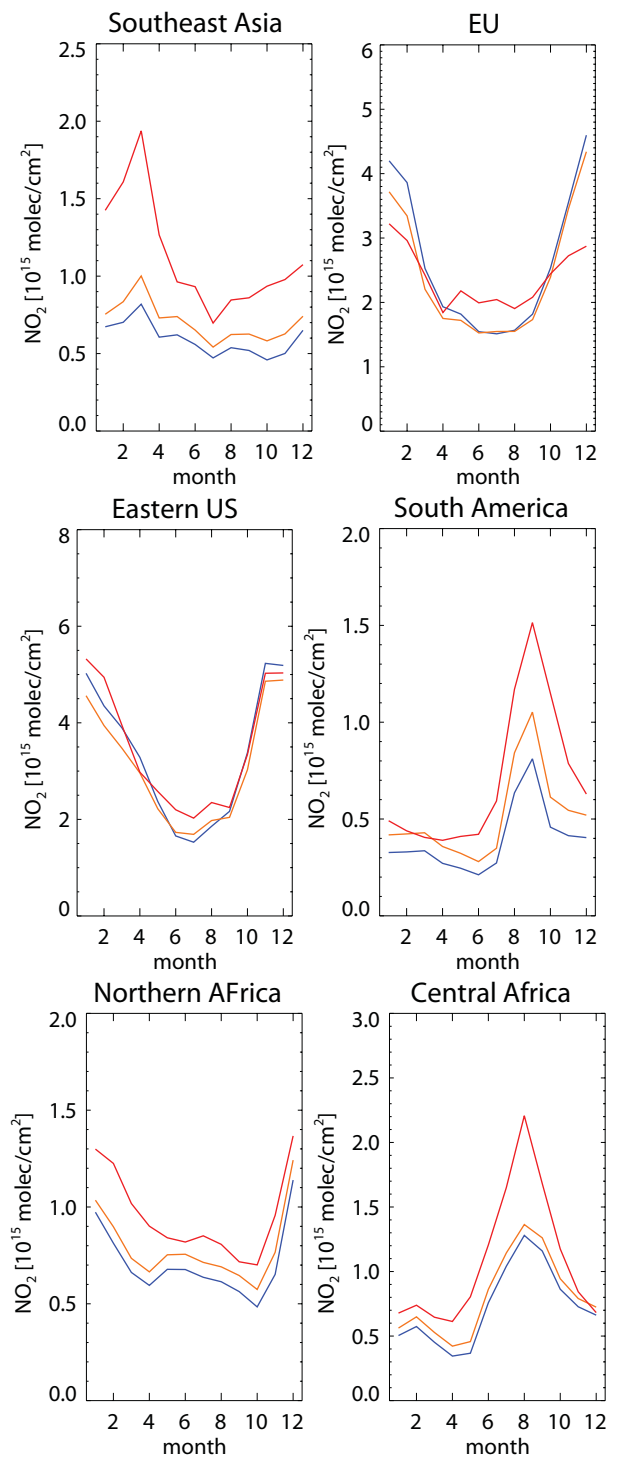

Fig. 8. The annual cycle of monthly averaged tropospheric columns of $\mathrm{NO}_{2}$ for selected global regions for the BA (blue), MBA (dark yellow) and OMI DOMINO v2 (red). The definition of the regions is thus: Southeast Asia $\left(98-105^{\circ} \mathrm{E}, 10-20^{\circ} \mathrm{N}\right)$, European Union $\left(10^{\circ} \mathrm{W}-30^{\circ} \mathrm{E}, 35-60^{\circ} \mathrm{N}\right)$, Eastern US $\left(71-90^{\circ} \mathrm{W}\right.$, $\left.31-43^{\circ} \mathrm{N}\right)$, South America $\left(50-70^{\circ} \mathrm{W}, 0-20^{\circ} \mathrm{S}\right)$, Northern Africa $\left(20^{\circ} \mathrm{W}-40^{\circ} \mathrm{E}, 0-20^{\circ} \mathrm{N}\right)$ and Central Africa $\left(10-40^{\circ} \mathrm{E}, 0-20^{\circ} \mathrm{S}\right)$.

the FT, the $\mathrm{O}_{3}$ comparisons in the boundary layer are more sensitive to regional uncertainties in the anthropogenic and aircraft $\mathrm{NO}_{\mathrm{x}}$ emission inventories employed (e.g. Jonson et al., 2010). The general ability of TM5 towards capturing the correct vertical distribution of tropospheric $\mathrm{O}_{3}$ at remote locations and the seasonal cycle at the surface is shown in Huijnen et al. (2010a). For brevity we do not repeat these comparisons here. The differences introduced by the MBA are limited to the range $\pm 5 \%$.
To examine the changes in the seasonal cycle in surface $\mathrm{O}_{3}$ under high $\mathrm{NO}_{\mathrm{x}}$ emissions, Fig. 7 shows comparisons against composites assembled from measurements taken at selected EMEP (European Monitoring and Evaluation Program) sites during 2006. A number of different comparisons are shown for different countries ranging from Sweden in northern Europe to Spain in southern Europe, thus covering a wide range of SZA (solar radiation) and atmospheric conditions. The sampling at EMEP sites is continuous which captures the diurnal cycle in tropospheric $\mathrm{O}_{3}$ throughout the day. Again model values are interpolated from TM5 output sampled every $3 \mathrm{~h}$ throughout the year taking into account the altitude of each site due to variable orography when assembling the composite. For the BA there is generally a negative bias for most of the year except in Spain. This is similar to that observed for TM5 at more pristine locations (Huijnen et al., 2010a). Although applying the MBA does not remove this artifact it significantly reduces the magnitude of this bias, especially during the winter and spring, generally reducing the model differences with surface $\mathrm{O}_{3}$ observations during the $\mathrm{NH}$ winter. For some locations e.g. Switzerland the model captures both the amplitude and phase of the seasonal cycle rather well, although there is a tendency for an overestimate during August for some countries, possibly related to deposition velocities (Ordñez et al., 2010). It should also be noted that no diurnal variation exists in $\mathrm{NO}_{\mathrm{x}}$ emissions, which could enhance titration of $\mathrm{O}_{3}$ during nighttime (Huijnen et al., 2010a), when the emissions from road transport decrease. Overall the increases in surface $\mathrm{O}_{3}$ (see Fig. S4 in the Supplement) using the MBA compared to the BA improve model performance when accounting for the full diurnal cycle of tropospheric $\mathrm{O}_{3}$.

\subsection{Nitrogen oxides $\left(\mathrm{NO}_{\mathrm{x}}\right)$}

Figure 5 shows that for tropospheric $\mathrm{NO}_{\mathrm{x}}$ the application of the MBA results in a vertical redistribution of reactive nitrogen from the LT (boundary layer) to the MT, which subsequently lowers surface $\mathrm{NO}_{\mathrm{x}}$ (see Fig. S4 in the Supplement) while mid-tropospheric $\mathrm{NO}_{\mathrm{x}}$ is significantly increased both in the tropics and in $\mathrm{NH}$ summer.

The corresponding perturbations in the zonally averaged seasonal means of the main $\mathrm{NO}_{\mathrm{x}}$ reservoirs $\left(\mathrm{PAN}\right.$ and $\left.\mathrm{HNO}_{3}\right)$ are shown in Fig. S7 of the Supplement. The higher resident $\mathrm{OH}$ results in a larger fraction of the emitted nitrogen being converted into $\mathrm{HNO}_{3}$ in the boundary layer (+18\%). Moreover, the in-situ chemical production term for $\mathrm{HNO}_{3}$ in the FT is also enhanced due to the longer lifetime of $\mathrm{NO}_{2}$ as a result of decreases in $J_{\mathrm{NO}_{2}}$ (see Fig. 1). The simultaneous reduction in $J_{\mathrm{HNO}_{3}}$ of between $\sim 0-10 \%$ subsequently increases the atmospheric lifetime of $\mathrm{HNO}_{3}$ which also helps increase the resident concentration in the FT $(+5-15 \%)$. The increase in $\mathrm{HNO}_{3}$ suppresses the formation of PAN near high $\mathrm{NO}_{\mathrm{x}}$ emission sources due to reducing that availability of $\mathrm{NO}_{2}$. Thus the long-range transport of reactive nitrogen into 
Table 3. As Table 2 but for $\mathrm{CO}$ and budget terms for the MBA given in $\mathrm{Tg} \mathrm{CO} \mathrm{yr}^{-1}$ during 2006.

\begin{tabular}{lllll}
\hline Budget Term & Global & SH & Tropics & NH \\
\hline Emissions & 1162 & 29.7 & 772.4 & 359.7 \\
Trop. Chem. Prod. & $1314(+10.0 \%)$ & $78(+4.7 \%)$ & $1026(+9.9 \%)$ & $210(+12.6 \%)$ \\
Tropo. Chem. Loss & $2259(+5.6 \%)$ & $173(+3.0 \%)$ & $1684(+5.4 \%)$ & $402(+7.7 \%)$ \\
Trop. Burden & $322(-0.7 \%)$ & $51(+0.6 \%)$ & $178(-0.3 \%)$ & $94(-2.0 \%)$ \\
Deposition & $180(+0.3 \%)$ & $6(+1.0 \%)$ & $101(+1.3 \%)$ & $73(-1.1 \%)$ \\
Lifetime (days) & $48.3(-5.5 \%)$ & & & \\
\hline
\end{tabular}

Table 4. As Table 2 but for $\mathrm{CH}_{2} \mathrm{O}$ and budget terms for the MBA given in $\mathrm{Tg}_{\mathrm{CH}} \mathrm{O} \mathrm{yr}^{-1}$.

\begin{tabular}{lllll}
\hline Budget Term & Global & SH & Tropics & NH \\
\hline Emissions & 27 & 1 & 18 & 8 \\
Tropo. Chem. Prod. & $1454(+3.5 \%)$ & $90(+2.3 \%)$ & $1139(+3.3 \%)$ & $224(+5.7 \%)$ \\
Trop. Chem. Loss & $1290(+5.5 \%)$ & $82(+3.1 \%)$ & $1006(+5.4 \%)$ & $202(+6.9 \%)$ \\
Trop. Burden & $0.67(-16.6 \%)$ & $0.04(-17.0 \%)$ & $0.50(-17.0 \%)$ & $0.13(-14.4 \%)$ \\
Deposition & $191(-12.5 \%)$ & $10(-17.2 \%)$ & $150(-12.8 \%)$ & $30(-9.7 \%)$ \\
\hline
\end{tabular}

more pristine regions is reduced, leading to decreases of between $\sim 0-10 \%$ in the tropospheric $\mathrm{NO}_{\mathrm{x}}$ in the extratropical SH during JJA. Total loss of nitrogen by wet deposition $\left(\sim 31 \mathrm{Tg} \mathrm{N} \mathrm{yr}^{-1}\right.$ ) does not change significantly due to the increased wet deposition of $\mathrm{HNO}_{3}$ being compensated for by an associated reduction in the wet deposition of organic nitrates (ORGNTR).

To investigate the change in the performance of TM5 for $\mathrm{NO}_{2}$ due to the MBA we make comparisons against OMI (Ozone Monitoring Instrument) observations from the DOMINO product (version 2.0, Boersma et al., 2011). In order to perform a valid comparison the TM5 $\mathrm{NO}_{2}$ fields are output at the local OMI overpass time of 13:30 local time and interpolated onto the satellite pixels. Averaging kernels are applied during the comparison as described in Huijnen et al. (2010b). This is the first time that TM5 has been compared to this new product, where the high bias of 0-30\% exhibited in the v1.02 product (e.g. Hains et al., 2009; Huijnen et al., 2010b) has been improved.

Figure 8 shows the seasonal cycle of integrated tropospheric $\mathrm{NO}_{2}$ columns for a number of selected regions for both of the model simulations and the DOMINO v2 product. It can be seen that TM5 captures the seasonal cycle observed in the measurements for all of the regions shown, albeit with a negative bias in most cases. For details regarding the spatial distribution of $\mathrm{NO}_{2}$ in TM5 during 2006 at global scale the reader is referred to the comparison performed in Huijnen et al. (2010a). Application of the MBA generally results in higher tropospheric $\mathrm{NO}_{2}$ columns. The exception is during the first months of 2006 in the polluted Eastern US region, where lower tropospheric $\mathrm{NO}_{2}$ columns occur using MBA compared to $\mathrm{BA}$. However, overall the MBA reduces the negative bias of TM5 $\mathrm{NO}_{2}$ towards the DOMINO v2 product.

\subsection{Carbon monoxide (CO)}

For tropospheric $\mathrm{CO}$ the inter-hemispheric perturbations introduced by the MBA compared to the BA are typically the inverse of those shown for tropospheric $\mathrm{O}_{3}$. This is due to the dominant chemical sink in the troposphere being the oxidation by $\mathrm{OH}$, where the perturbations in $\mathrm{OH}$ shown in Fig. 5 are governed by the perturbations in $J_{\mathrm{O}^{1} \mathrm{D}}$ and the changes in the resident concentration of $\mathrm{O}_{3}$.

The changes in the annual chemical budget terms for tropospheric $\mathrm{CO}$ are given in Table 3. Examining the in-situ chemical production and destruction terms shows that there is a cancellation of effects, where the additional $\mathrm{CO}$ produced from the more rapid oxidation of Non-Methane Volatile Organic Compounds (NMVOCs) is removed due to the enhanced $\mathrm{OH}$. The dominant chemical reactions which are responsible for the enhancement in the in-situ chemical production term for $\mathrm{CO}$ are the enhanced photolysis of $\mathrm{CH}_{2} \mathrm{O}$ and higher aldehydes (ALD2). The reduction in the atmospheric lifetime of $\mathrm{CO}$ provides evidence that application of the MBA leads to an increase in the oxidative capacity of the troposphere in TM5 (see Sect. 5). The equilibrium of the modified CBM4 chemical mechanism (Houweling et al., 1998) is maintained with respect to CO resulting in an insignificant change in the total global burden.

Using similar emission inventories to those used in this study Huijnen et al. (2010a) found that TM5 generally underpredicted $\mathrm{CO}$ in the $\mathrm{NH}$ when using the BA, especially at high latitudes and in the UT. The small perturbation in the global distribution of $\mathrm{CO}$ shown in Fig. 5 does not lead to any significant improvement towards this negative bias by using the MBA. For instance, comparisons of tropospheric $\mathrm{CO}$ profiles made against composites based on MOZAIC 

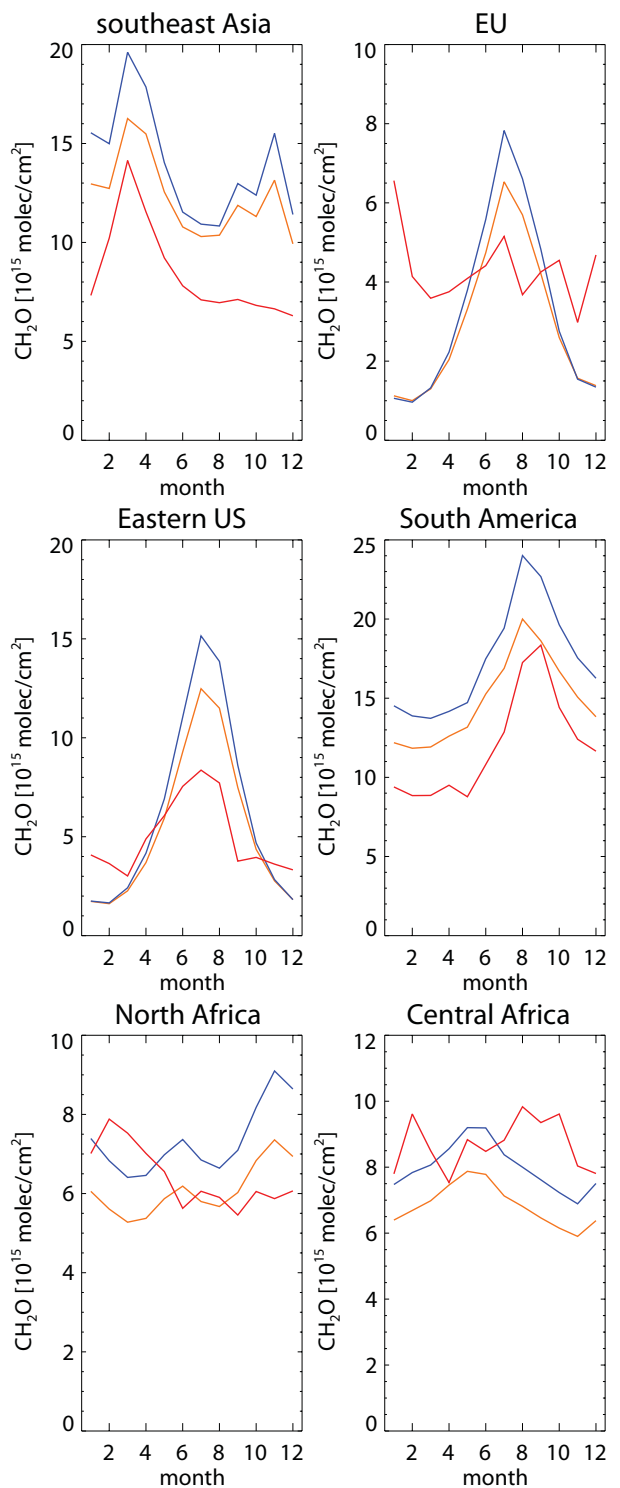

Fig. 9. The annual cycle of monthly averaged tropospheric columns of $\mathrm{CH}_{2} \mathrm{O}$ for selected global regions for the BA (blue), MBA (dark yellow) and SCIAMACHY (red). For the latitudinal and longitudinal constraints of each region the reader is referred to the legend of Fig. 7.

measurements (similar to those performed in Fig. 6) show that negative biases of the order of $\sim 20 \%$ occur for TM5, using either the BA or the MBA, throughout the LT and MT (not shown). The differences introduced in the surface concentrations are of the order of a few ppb, where the seasonal cycle is also nearly identical to that shown previously (Huijnen et al., 2010a).

\subsection{Formaldehyde $\left(\mathrm{CH}_{2} \mathrm{O}\right)$}

The changes in the zonally averaged $J_{\mathrm{CH}_{2} \mathrm{O}}$ and global distribution of $\mathrm{CH}_{2} \mathrm{O}$ for both seasons are shown in Figs. S6 and S7 of the Supplement, respectively. For $\mathrm{CH}_{2} \mathrm{O}$ the highest mixing ratios occur in the tropical LT and are typically associated with high isoprene emissions (as a major oxidation product). The enhanced photolysis of $\mathrm{CH}_{2} \mathrm{O}$ in the MBA causes decreases of the order of $\sim 5-10 \%$ near these regions. One obvious feature is a substantial relative increase in the mixing ratio of $\mathrm{CH}_{2} \mathrm{O}$ in instances of low sun, although these increases relate to rather low mixing ratios.

The changes in the annual chemical budget terms for tropospheric $\mathrm{CH}_{2} \mathrm{O}$ are given in Table 4. The in-situ chemical production of $\mathrm{CH}_{2} \mathrm{O}$ dominates the direct emissions due to anthropogenic and biomass burning activity. The MBA increases the contribution due to this term by $\sim 6 \%$ mainly from an increase in the photolysis of ALD2 and the increased oxidation of methylperoxide $\left(\mathrm{CH}_{3} \mathrm{O}_{2} \mathrm{H}\right)$ by $\mathrm{OH}$. However, the increase in $J_{\mathrm{CH}_{2} \mathrm{O}}$ by $\sim 30-50 \%(\sim 60-70 \%)$ in the MT (LT) reduces the global burden and subsequently shortens the atmospheric lifetime. There is an associated reduction in the loss by both dry and wet deposition (equivalent to 9.6 $\mathrm{Tg} \mathrm{C} \mathrm{yr}^{-1}$ ).

Figure 9 shows comparisons of monthly mean total columns of $\mathrm{CH}_{2} \mathrm{O}$ for both simulations against BIRA/KNMI retrievals derived from SCIAMACHY observations (De Smedt et al., 2008) interpolated onto the model resolution of $3^{\circ} \times 2^{\circ}$, similar to that shown for $\mathrm{NO}_{2}$. Here no averaging kernels are used and the true monthly average of TM5 for 10:30 local time is compared. The same definition of the different regions is used as in Fig. 8. The accuracy of the SCIAMACHY retrievals is of the order of $\sim 20-40 \%$ (De Smedt et al., 2008). It has been shown that TM5 exhibits positive biases for regions such as the Eastern US during JJA and South America (Huijnen et al., 2010a). The comparisons in Fig. 9 show that application of the MBA improves on these positive biases for regions with high biogenic emissions e.g. South-East Asia and South America. For the EU the amplitude of the seasonal cycle is over-estimated by TM5, where there appears to be a missing anthropogenic emission or precursor emission source during DJF when biogenic activity is low. However, there is an improvement in the positive bias observed during JJA, as for the Eastern US. For Africa the seasonal cycle is almost inverted by TM5 for the North, whilst exhibiting a maximum during May for Central Africa. Given the errors associated with the SCIAMACHY product it is difficult to use such comparisons to put emphasis on artefacts such as the accuracy of the isoprene emission inventory or yield from biomass burning. 


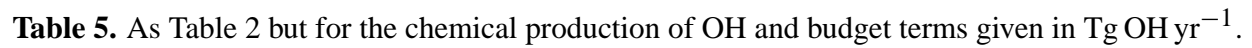

\begin{tabular}{lllll}
\hline Budget Term & Global & $\mathrm{SH}$ & Tropics & $\mathrm{NH}$ \\
\hline $\mathrm{O}\left({ }^{1} \mathrm{D}\right)+\mathrm{H}_{2} \mathrm{O}$ & $1663(+4.1 \%)$ & $113(+4.7 \%)$ & $1340(+4.0 \%)$ & $210(+4.5 \%)$ \\
$\mathrm{NO}+\mathrm{HO}_{2}$ & $1063(+6.0 \%)$ & $68(+1.2 \%)$ & $762(+5.7 \%)$ & $233(+8.3 \%)$ \\
$\mathrm{O}_{3}+\mathrm{HO}_{2}$ & $423(+5.6 \%)$ & $39(+2.2 \%)$ & $289(+5.2 \%)$ & $95(+8.5 \%)$ \\
$\mathrm{H}_{2} \mathrm{O}_{2}+h v$ & $211(-7.8 \%)$ & $18(-10.5 \%)$ & $163(-7.3 \%)$ & $29(-9.3 \%)$ \\
Remainder & $160(-10.1 \%)$ & $11(+6.8 \%)$ & $128(-40.5 \%)$ & $23(-8.3 \%)$ \\
Total production & $3522(+3.2 \%)$ & $248(+1.6 \%)$ & $2685(+3.1 \%)$ & $590(+5.1 \%)$ \\
\hline
\end{tabular}

Table 6. Details regarding the total mass of each trace species $\left(\mathrm{Tg} \mathrm{yr}^{-1}\right)$ oxidized per year in the MBA simulation. The percentage changes between the BA and MBA simulation are also given using the MBA/BA ratio.

\begin{tabular}{llrllr}
\hline $\begin{array}{l}\text { Trace } \\
\text { species }\end{array}$ & $\begin{array}{l}\text { Loss in Tg } \\
\text { species yr }\end{array}$ & $\begin{array}{r}\% \text { OH } \\
\text { loss }\end{array}$ & $\begin{array}{l}\text { Trace } \\
\text { species }\end{array}$ & $\begin{array}{l}\text { Loss in } \mathrm{Tg} \\
\text { species yr }\end{array}$ & $\begin{array}{r}\% \mathrm{OH} \\
\text { loss }\end{array}$ \\
\hline $\mathrm{CH}_{4}$ & $575(+5.1 \%)$ & 15.5 & $\mathrm{CH}_{2} \mathrm{O}$ & $91(-9.6 \%)$ & 4.6 \\
$\mathrm{CO}$ & $777(+5.9 \%)$ & 39.3 & $\mathrm{ALD}_{2}$ & $47(-32.8 \%)$ & 1.9 \\
$\mathrm{ISOP}$ & $21(+1.0 \%)$ & 2.4 & $\mathrm{CH}_{3} \mathrm{O}_{2} \mathrm{H}$ & $73(+5.5 \%)$ & 6.0 \\
$\mathrm{SO}_{2}$ & $3(+9.6 \%)$ & 0.3 & $\mathrm{H}_{2} \mathrm{O}_{2}$ & $64(+16.8 \%)$ & 3.7 \\
$\mathrm{DMS}$ & $2(+1.1 \%)$ & 0.2 & $\mathrm{HNO}_{3}$ & $1(+7.4 \%)$ & 0.1 \\
$\mathrm{O}_{3}$ & $70(+5.0 \%)$ & 5.1 & $\mathrm{HO}_{2}$ & $94(+7.1 \%)$ & 4.9 \\
$\mathrm{NO}_{2}$ & $11(+13.2 \%)$ & 0.9 & $\mathrm{H}_{2}$ & $1511(+5.1 \%)$ & 5.1 \\
\hline
\end{tabular}

\section{Implications for oxidative capacity of the troposphere}

The large perturbations in $\mathrm{OH}$ shown in Fig. 5 increase the oxidative capacity of the troposphere markedly when integrated over the entire year. In order to quantify this, Table 5 shows the change in the globally integrated annual production rate from the four main photochemical pathways of $\mathrm{OH}$ generation in the modified CBM4 mechanism (Houweling et al., 1998). Here the totals are given in $\mathrm{Tg} \mathrm{OH} \mathrm{yr}^{-1}$ together with the relative differences when compared against the BA. All terms increase apart from the $J$-value of hydrogen peroxide $\left(\mathrm{H}_{2} \mathrm{O}_{2}, J_{\mathrm{H}_{2} \mathrm{O}_{2}}\right)$, where a lower $J_{\mathrm{H}_{2} \mathrm{O}_{2}}$ in the MBA reduces net photochemical destruction (see Fig. S7 in the Supplement). Summing individual terms shows that a net global increase of $\sim 3 \%$ occurs in the global production term for $\mathrm{OH}$, with the largest increase being associated with $J_{\mathrm{O}^{1} \mathrm{D}}$.

Table 6 shows the resulting perturbation in the total mass of each trace species subsequently oxidized by $\mathrm{OH}$. A true measure of the changes in the oxidative capacity of the troposphere can be assessed by looking at the ubiquitous gases such as $\mathrm{CH}_{4}$ and $\mathrm{H}_{2}$, where there are increases of between $\sim 4-5 \%$ in tropospheric mass that is oxidized. This subsequently reduces the atmospheric lifetime of $\mathrm{CH}_{4}$ from 8.72 to $8.35 \mathrm{yr}$, a reduction of $\sim 4.4 \%$. Although the changes in tropospheric $\mathrm{CO}$ due to more efficient in-situ production are limited to a few percent (cf. Fig. 5), CO acts as the most effective chemical scavenger of $\mathrm{OH}$ in the troposphere, where

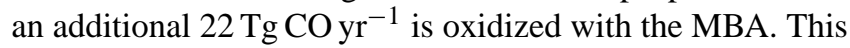
introduces a moderating effect towards the increases in the oxidation of the other trace gas species due to the enhanced oxidising capacity. A more efficient photolysis of $\mathrm{CH}_{2} \mathrm{O}$ and ALD2 reduces the fraction of $\mathrm{OH}$ lost by direct scavenging $(-30 \%)$ and the decrease in $J_{\mathrm{H}_{2} \mathrm{O}_{2}}$ increases mixing ratios of $\mathrm{H}_{2} \mathrm{O}_{2}$ significantly $(\sim 30-50 \%)$ (and thus the mass oxidized by $\mathrm{OH}$ ).

\section{Summary}

The optimization and integration of the Modified Band Approach into the large-scale 3-D chemistry transport model TM5 for the calculation of photo-dissociation rate constants ( $J$-values) has been comprehensively described and evaluated. We have shown that many of the resulting $J$-values increase by $\sim 5-20 \%$ in the planetary boundary layer and decrease by $\sim 5-10 \%$ in the middle troposphere of the tropics when compared against a more parameterized photolysis scheme. These changes are due to the cumulative effects of updating photolytic reaction data, applying an updated method for the calculation of the solar zenith angles, the use of red-shifted band intervals for low sun, a modification of the top of the atmosphere solar spectrum, the calculation of actinic fluxes for each specific model column, the use of an explicit aerosol climatology with lower OD than was implicitly assumed in the parameterization, and improvements in the description of the scattering and absorbance by clouds and cirrus particles. 
Analysing the chemical budget shows that the $\mathrm{NO}_{\mathrm{x}}$ recycling efficiency increases markedly causing an associated increase in tropospheric $\mathrm{O}_{3}$ formation, especially in the lower troposphere close to regions which exhibit high $\mathrm{NO}_{\mathrm{x}}$ emissions. Perturbations in the main reservoir species for $\mathrm{HO}_{\mathrm{x}}$ and $\mathrm{NO}_{\mathrm{x}}$ occur, resulting in less resident PAN and $\mathrm{CH}_{2} \mathrm{O}$. The increase in $\mathrm{HNO}_{3}$ in the middle troposphere introduces more $\mathrm{NO}_{2}$ at tropical latitudes and in the Northern Hemisphere during boreal summer. On balance the transport of reactive nitrogen to more remote locations as PAN is reduced, subsequently suppressing background tropospheric $\mathrm{O}_{3}$ formation.

Comparing the relationship between monthly mean $\mathrm{OH}$ concentrations at the surface and the photolysis rate of $\mathrm{O}_{3}$ shows that the MBA gives a relationship which is closer to that determined from surface measurements, although the calculated values of $J_{\mathrm{O}^{1} \mathrm{D}}$ are high during boreal summertime. When comparing the resulting distribution of $\mathrm{O}_{3}$ against both ground-based measurements and tropospheric profiles taken in Europe there is an improvement in the performance of TM5 at the surface in the Northern Hemisphere during boreal winter and in the middle troposphere throughout the year. For tropospheric $\mathrm{CO}$ a significant underestimation remains throughout the troposphere. An increase of $\sim 10 \%$ in the in-situ CO chemical production term is compensated for by enhanced chemical loss, thus maintaining the chemical equilibrium of the modified CBM4 mechanism, resulting in changes of a few percent in the resident $\mathrm{CO}$ mixing ratios. Both the total column $\mathrm{NO}_{2}$ and total column $\mathrm{CH}_{2} \mathrm{O}$ show improvements when compared against satellite composites, where the seasonal cycles remain similar.

The increase in the mixing ratio and photodissociation rate of tropospheric $\mathrm{O}_{3}$ causes an increase in tropospheric $\mathrm{OH}$. The oxidative capacity of the troposphere in TM5 is therefore enhanced and the total annual mass of trace species oxidized increases $\left(\mathrm{CH}_{4}:+5.1 \%\right.$; $\left.\mathrm{CO}:+5.9 \%\right)$. The atmospheric lifetimes of $\mathrm{CO}$ and $\mathrm{CH}_{4}$ are thus reduced by $\sim 5 \%$ and $\sim 4 \%$, respectively.

The flexibility of the MBA allows for additional processes to be easily introduced into the calculation of $J$-values e.g. aerosol scattering and absorption and changes in cloud parameters. The approach can also be tailored to other chemical schemes by the inclusion of additional absorption parameters and quantum yields, e.g. allowing the accurate description of the photolysis of acetone. It is envisaged that future applications could also benefit by the replacement of the 2-stream radative transfer solver used here by fast and even more accurate 4-, 6-, or 8-stream solvers which are readily available. In its current form the application of the MBA results in a $\sim 15 \%$ increase in run-time, although this is dependent on the method of parallelization used and the scalability of any large scale model.

\author{
Supplementary material related to this \\ article is available online at: \\ http://www.geosci-model-dev.net/5/15/2012/ \\ gmd-5-15-2012-supplement.pdf.
}

Acknowledgements. We thank M. C. Krol for stimulating discussions and recommendations regarding the optimization of the photolysis scheme. SCIAMACHY is a joint project of the german Space Agency DLR and the Dutch Space Agency NIVR with contribution from the Belgian Space Agency. The OMI project is managed by NIVR and KNMI in The Netherlands. The authors acknowledge for the strong support of the European Commission, Airbus, and the Airlines (Lufthansa, Austrian, Air France) who carry free of charge the MOZAIC equipment and perform the maintenance since 1994. MOZAIC is presently funded by INSUCNRS (France), Météo-France, and Forschungszentrum Jülich (Germany). The MOZAIC data based is supported by ETHER (CNES and INSU-CNRS).

Edited by: K. Gierens

\section{References}

Aan de Brugh, J. M. J., Schaap, M., Vignati, E., Dentener, F., Kahnert, M., Sofiev, M., Huijnen, V., and Krol, M. C.: The European aerosol budget in 2006, Atmos. Chem. Phys., 11, 1117-1139, doi:10.5194/acp-11-1117-2011, 2011.

Anderson, G., Clough, S., Kneizys, F., Chetwynd, J., and Shettle, E.: AFGL atmospheric constituent profiles $(0-120 \mathrm{~km})$, AFGLTR-86-0110, Air Force Geophys. Lab., Hanscom Air Force Base, Bedford, Mass, 1986.

Atkinson, R., Baulch, D. L., Cox, R. A., Crowley, J. N., Hampson, R. F., Hynes, R. G., Jenkin, M. E., Rossi, M. J., Troe, J., and IUPAC Subcommittee: Evaluated kinetic and photochemical data for atmospheric chemistry: Volume II - gas phase reactions of organic species, Atmos. Chem. Phys., 6, 3625-4055, doi:10.5194/acp-6-3625-2006, 2006.

Boersma, K. F., Eskes, H. J., Dirksen, R. J., van der A, R. J., Veefkind, J. P., Stammes, P., Huijnen, V., Kleipool, Q. L., Sneep, M., Claas, J., Leitão, J., Richter, A., Zhou, Y., and Brunner, D.: An improved tropospheric $\mathrm{NO}_{2}$ column retrieval algorithm for the Ozone Monitoring Instrument, Atmos. Meas. Tech., 4, 19051928, doi:10.5194/amt-4-1905-2011, 2011.

Brasseur, G. P., Hauglustaine, D. A., Walters, S., Rasch, P. J., Muller, J.-F., Granier, C., and Tie, X.: MOZART: a global tracer model for ozone and related chemcial tracers, 1 . Model description, J. Geophys. Res., 103, 28265-28289, 1998.

Brühl, C. and Crutzen, P. J.: Scenarios of possible changes in atmospheric temperatures and ozone concentrations due to man's activities, estimated with a one-dimensional coupled photochemical climate model, Clim. Dynam., 2, 173-203, 1988.

De Smedt, I., Müller, J.-F., Stavrakou, T., van der A, R., Eskes, H., and Van Roozendael, M.: Twelve years of global observations of formaldehyde in the troposphere using GOME and SCIAMACHY sensors, Atmos. Chem. Phys., 8, 4947-4963, doi:10.5194/acp-8-4947-2008, 2008

Dee, D. P., Uppala, S. M., Simmons, A. J., Berrisford, P., Poli, P., Kobayashi, S., Andrae, U., Balmaseda, M. A., Balsamo, G., 
Bauer, P., Bechtold, P., Beljaars, A. C. M., van de Berg, L., Bidlot, J., Bormann, N., Delsol, C., Dragani, R., Fuentes, M., Geer, A. J., Haimberger, L., Healy, S. B., Hersbach, H., Hólm, E. V., Isaksen, L., Kållberg, P., Köhler, M., Matricardi, M., McNally, A. P., Monge-Sanz, B. M., Morcrette, J.-J., Park, B.-K., Peubey, C., de Rosnay, P., Tavolato, C., Thépaut, J.-N., and Vitart, F.: The ERA-Interim reanalysis: configuration and performance of the data assimilation system, Q. J. Roy. Meteorol. Soc., 137, 553597, doi:10.1002/qj.828, 2011.

Dickerson, R. R., Stedman, D. H., and Delany, A. C.: Direct Measurements of ozone and Nitrogen Dioxide Photolysis Rates in the Troposphere, J. Geophys. Res., 87, 4933-4946, 1982.

Dobber, M., Voors, R., Dirksen, R., Kleipool, Q., and Levelt, P.: The high-resolution solar reference spectrum between 250 and $550 \mathrm{~nm}$ and its application to measurements with the Ozone Monitoring Instrument, Solar Phys., 249, 281-291, doi:10.1007/s11207-008-9187-7, 2008.

Ehhalt, D. H. and Rohrer, F.: Dependence of the $\mathrm{OH}$ concentration on solar UV, J. Geophys. Res., 105, 3565-3571, 2000.

Elterman, L.: UV, visible and IR attenuation for altitudes to 50km, Environmental Research Papers, No. 285, Report 680153, Air Force Cambridge Research Laboratories, Bedford, Massachusetts, United States, 1968.

Fortuin, J. P. F. and Kelder, H.: An ozone climatology based on ozonesonde and satellite measurements, J. Geophys. Res., 103, 31709-31734, 1998.

Fu, Q.: An Accurate Parameterization of the solar Radiative Properties of Cirrus Clouds for Climate Models, J. Climate, 9, 20582082, 1996.

Geleyn, J. F. and Hollingsworth, A.: An Economical analytical method for the computation of the interaction between scattering and line absorption of radiation, Contrib. Atmos. Phys., 52, 1-16, 1979.

Guenther, A., Hewitt, C. N., Erickson, D., Fall, R., Geron, C., Graedel, T., Harley, P., Klinger, L., Lerdau, M., Mckay, W. A., Pierce, T., Scholes, B., Steinbrecher, R., Tallamraju, R., Taylor, J. and Zimmerman, P.: A global model of natural volatile organic compound emissions, J. Geophys. Res., 100, 8873-8892, 1995.

Hains, J. C., Boersma, K. F., Kroon, M., Dirksen, R. J., Cohen, R. C., Perring, A. E., Bucsela, E., Volten, H., Swart, D. P. J., Richter, A., Wittrock, F., Schoenhardt, A., Wagner, T., Ibrahim, O. W., van Roozendaal, M., Pinardi, G., Gleason, J. F., Veefkind, J. P., and Levelt, P.: Testing and improving the OMI DOMINO tropospheric $\mathrm{NO}_{2}$ using observations from the DANDELIONS and INTEX-B validation campaigns, J. Geophys. Res., 115, D05301, doi:10.1029/2009JD012399, 2010.

Heymsfield, A. J., Winker, D., and van Zadelhoff, G.-J.: Extinctionice water content-effective radius algorithms for CALIPSO, Geophys. Res. Lett., 32, L10807, doi:10.1029/2005GL022742, 2005.

Hofzumahaus, A., Lefer, B. L., Monks, P. S., Hall, S. R., Kylling, A., Mayer, B., Shetter, R. E., Junkermann, W., Bais, A., Calvert, J. G., Cantrell, C. A., Madronich, S., Edwards, G. D., Kraus, A., Muller, M., Bohn, B., Schmitt, R., Johnson, P., Mckenzie, R., Frost, G. J., Griffioen, E., Krol, M., Martin, T., Roth, E. P., Ruggaber, A., Swartz, W. H., Lloyd, S. A., and van Weele, M.: Photolysis frequency of $\mathrm{O}_{3}$ to $\mathrm{O}\left({ }^{1} \mathrm{D}\right)$ : Measurements and modeling during the International Photolysis Frequency Measurement and Modeling Intercomparison (IPMMI), J. Geophys. Res., 109, D08S90, doi:10.1029/2003JD004333, 2004.
Houweling, S., Dentener, F. J., and Lelieveld, J.: The impact of nonmethane hydrocarbon compounds on tropospheric photochemistry, J. Geophys. Res., 103, 10673-10696, 1998.

Huijnen, V., Williams, J., van Weele, M., van Noije, T., Krol, M., Dentener, F., Segers, A., Houweling, S., Peters, W., de Laat, J., Boersma, F., Bergamaschi, P., van Velthoven, P., Le Sager, P., Eskes, H., Alkemade, F., Scheele, R., Nédélec, P., and Pätz, H.-W.: The global chemistry transport model TM5: description and evaluation of the tropospheric chemistry version 3.0, Geosci. Model Dev., 3, 445-473, doi:10.5194/gmd-3-445-2010, 2010 a.

Huijnen, V., Eskes, H. J., Poupkou, A., Elbern, H., Boersma, K. F., Foret, G., Sofiev, M., Valdebenito, A., Flemming, J., Stein, O., Gross, A., Robertson, L., D’Isidoro, M., Kioutsioukis, I., Friese, E., Amstrup, B., Bergstrom, R., Strunk, A., Vira, J., Zyryanov, D., Maurizi, A., Melas, D., Peuch, V.-H., and Zerefos, C.: Comparison of $\mathrm{OMI} \mathrm{NO}_{2}$ tropospheric columns with an ensemble of global and European regional air quality models, Atmos. Chem. Phys., 10, 3273-3296, doi:10.5194/acp-10-3273-2010, $2010 \mathrm{~b}$.

Jöckel, P., Tost, H., Pozzer, A., Brühl, C., Buchholz, J., Ganzeveld, L., Hoor, P., Kerkweg, A., Lawrence, M. G., Sander, R., Steil, B., Stiller, G., Tanarhte, M., Taraborrelli, D., van Aardenne, J., and Lelieveld, J.: The atmospheric chemistry general circulation model ECHAM5/MESSy1: consistent simulation of ozone from the surface to the mesosphere, Atmos. Chem. Phys., 6, 50675104, doi:10.5194/acp-6-5067-2006, 2006.

Jonson, J. E., Stohl, A., Fiore, A. M., Hess, P., Szopa, S., Wild, O., Zeng, G., Dentener, F. J., Lupu, A., Schultz, M. G., Duncan, B. N., Sudo, K., Wind, P., Schulz, M., Marmer, E., Cuvelier, C., Keating, T., Zuber, A., Valdebenito, A., Dorokhov, V., De Backer, H., Davies, J., Chen, G. H., Johnson, B., Tarasick, D. W., Stübi, R., Newchurch, M.J., von der Gathen, P., Steinbrecht, W., and Claude, H.: A multi-model analysis of vertical ozone profiles, Atmos. Chem. Phys., 10, 5759-5783, doi:10.5194/acp10-5759-2010, 2010.

Koelemeijer, R. B. A., de Haan, J. F., and Stammes, P.: A database of spectral surface reflectivity in the range $335-772 \mathrm{~nm}$ derived from 5.5 years of GOME observations, J. Geophys. Res., 108, 4070-4083, doi:10.1029/2002JD002429, 2003.

Kraus, A. and Hofzumahaus, A.: Field Measurements of Atmospheric Photolysis Frequencies for $\mathrm{O}_{3}, \mathrm{NO}_{2}, \mathrm{HCHO}, \mathrm{CH}_{3} \mathrm{CHO}$, $\mathrm{H}_{2} \mathrm{O}_{2}$ and $\mathrm{HONO}$ by UV Spectroradiometery, J. Atmos. Chem., 31, 161-180, 1998.

Krol, M. C. and van Weele, M.: Implications of variations in photodissociation rates for global tropospheric chemistry, Atmos. Environ., 31, 1257-1273, 1997.

Landgraf, J. and Crutzen, P. J.: An Efficient Method for online calculations of Photolysis and Heating Rates, J. Atmos. Sci., 55, 863-878, 1998.

Law, K. S. and Pyle, J. A.: Modeling trace gas budgets in the troposphere 1, Ozone and odd nitrogen, J. Geophys. Res., 98, 1837718400, 1993.

Lathière, J., Hauglustaine, D. A., Friend, A. D., De NobletDucoudré, N., Viovy, N., and Folberth, G. A.: Impact of climate variability and land use changes on global biogenic volatile organic compound emissions, Atmos. Chem. Phys., 6, 2129-2146, doi:10.5194/acp-6-2129-2006, 2006.

Lelieveld, J., Peters, W., Dentener, F. J., and Krol, M. C.: Stability of the tropospheric hydroxyl radical, J. Geophys. Res., 107, 4715, doi:10.1029/2002JD002272, 2002. 
Liu, H., Crawford, J. H., Pierce, R. B., Norris, P., Platnick, S. E., Chen, G., Logan, J. A., Evans, J. Mat, Kittaka, C., Feng, Y., and Tie, X.: Radiative effects of clouds on tropospheric chemistry in a global three-dimensional chemical transport model, J. Geophys. Res., 111, doi:10.1029/2005JD006403, 2006.

McFarlane, N. A., Boer, G. J., Blanchet, J.-P., and Lazare, M.: The Canadian Climate Centre second-generation general circulation model and its equilibrium climate, J. Climate, 5, 1013-1044, 1992.

Madronich, S.: Photodissociation in the atmosphere: 1. Actinic Flux and the effect of ground reflections and clouds, J. Geophys. Res., 92, 9740-9752, 1987.

Madronich, S. and Weller, G: Numerical integration errors in calculated tropospheric photodissociation rate co-efficients, J. Atmos. Chem., 10, 289-300, 1990.

Marenco, A., Thouret, V., Nédélec, P., Smit, H., Helten, M., Kley, D., Karcher, F., Simon, P., Law, K., Pyle, J., Poschmann, G., Von Wrede, R., Hume, C. and Cook, T.: Measurement of ozone and water vapor by Airbus in-service aircraft: The MOZAIC airborne program, An overview, J. Geophys. Res., 103, 25631-25642, 1998.

Martin, R. V., Jacob, D. J., Yantosca, R. M., Chin, M., and Ginoux, P.: Global and regional decreases in tropospheric oxidants from photochemical effects of aerosols, J. Geophys. Res., 108, 4097, doi:10.1029/2002JD002622, 2003.

Matsumi, Y., Comes, F. J., Hancock, G., Hofzumahus, A., Hynes, A. J., Kawasaki, M., and Ravishankara, A. R.: Quantum yields for the production of $\mathrm{O}\left({ }^{1} \mathrm{D}\right)$ in the ultraviolet photolysis of ozone: recommendation based on evaluation of laboratory data, J. Geophys. Res., 107, 4024, doi:10.1029/2001JD000510, 2002.

Meijer, E. W., van Velthoven, P. F. J., Brunner, D. W., Huntrieser, H., and Kelder, H.: Improvement and evaluation of the parameterisation of nitrogen oxide production by lightning, Phys. Chem. Earth, 26, 557-583, 2001.

Monge-Sanz, B. M., Chipperfield, M. P., Simmons, A. J., and Uppala, S. M.: Mean age of air and transport in a CTM: Comparison of different ECMWF analyses, Geophys. Res. Lett., 34, L04801, doi:10.1029/2006GL028515, 2007.

Neckel, H. and Labs, D.: The Solar radiation between 3300 and 12500 Å, Solar Phys., 90, 205-258, 1984.

Nicolet, M.: On the molecular scattering in the terrestrial atmosphere: an empirical formula for it's calculation in the homosphere, Planet. Space Sci., 32, 1467-1468, 1984.

Ohara, T., Akimoto, H., Kurokawa, J., Horii, N., Yamaji, K., Yan, X., and Hayasaka, T.: An Asian emission inventory of anthropogenic emission sources for the period 1980-2020, Atmos. Chem. Phys., 7, 4419-4444, doi:10.5194/acp-7-4419-2007, 2007.

Ordóñez, C., Elguindi, N., Stein, O., Huijnen, V., Flemming, J., Inness, Flentje, H., Katragkou, E., Moinat, P., Peuch, V.-H., Segers, A., Thouret, V., Athier, G., van Weele, M., Zerefos, C. S., Cammas, J.-P. and Schultz, M. G.: Global model simulations of air pollution during the 2003 European heat wave, Atmos. Chem. Phys., 10, 789-815, doi:10.5194/acp-10-789-2010, 2010.

Prather, M. J.: Tropospheric $\mathrm{O}_{3}$ from photolysis of $\mathrm{O}_{2}$, Geophys. Res. Letts., 36, L03811, doi:10.1029/2008GL036851, 2009.

Rohrer, F. and Berresheim, H.: Strong correlation between levels of tropospheric hydroxyl radical and solar ultraviolet radiation, Nature, 442, 184-187, doi:10.1038/nature04924, 2006.
Sander, S. P., Abbatt, J. R., Burkholder, J. B., Friedl, R. R., Golden, D. M., Huie, R. E., Kolb, C. E., Kurylo, G., Moortgat, K., Orkin, V. L. and Wine, P.H.: Chemical kinetics and Photochemical Data for Use in Atmospheric studies, Evaluation No.17, JPL Publication 10-6, Jet Propulsion Laboratory, Pasadena, available at: http://jpldataeval.jpl.nasa.gov, 2011.

Schultz, M. G., Backman, L., Balkanski, Y., Bjoerndalsaeter, S., Brand, R., Burrows, J. P., Dalsoeren, S., de Vasconcelos, M., Grodtmann, B., Hauglustaine, D. A., Heil, A., Hoelzemann, J. J., Isaksen, I. S. A., Kaurola, J., Knorr, W., LadstaetterWeissenmayer, A., Mota, B., Oom, D., Pacyna, J., Panasiuk, D., Pereira, J. M. C., Pulles, T., Pyle, J., Rast, S., Richter, A., Savage, N., Schnadt, C., Schulz, M., Spessa, A., Staehelin, J., Sundet, J. K., Szopa, S., Thonicke, K., van het Bolscher, M., van Noije, T., van Velthoven, P., Vik, A. F., and Wittrock, F.: REanalysis of the TROpospheric chemical composition over the past 40 years (RETRO) - A long-term global modeling study of tropospheric chemistry, Final Report, Jülich/Hamburg, Germany, 2007 (Published as report no. 48/2007 in the series "Reports on Earth System Science" of the Max Planck Institute for Meteorology, Hamburg, ISSN 1614-1199), 2007.

Shettle, E. P. and Fenn, R. W.: Models for the aerosols of the lower atmosphere and the effects of the humidity variations on their optical properties, Environ. Res. Paper, 676, AFGL-TR-79-0114, 91 pp., 1979.

Schulz, M., Textor, C., Kinne, S., Balkanski, Y., Bauer, S., Berntsen, T., Berglen, T., Boucher, O., Dentener, F., Guibert, S., Isaksen, I. S. A., Iversen, T., Koch, D., Kirkevåg, A., Liu, X., Montanaro, V., Myhre, G., Penner, J. E., Pitari, G., Reddy, S., Seland, Ø., Stier, P., and Takemura, T.: Radiative forcing by aerosols as derived from the AeroCom present-day and pre-industrial simulations, Atmos. Chem. Phys., 6, 5225-5246, doi:10.5194/acp-6-5225-2006, 2006.

Slingo, A.: A GCM Parameterization for the Shortwave Radiative Properties of Water Clouds, J. Atms. Sci., 46, 1419-1427, 1989.

Stevenson, D. S., Dentener, F. J., Schultz, M. G., Ellingsen, K., van Noije, T. P. C., Wild, O., Zeng, G., Amann, M., Atherton, C. S., Bell, N., Bergmann, D. J., Bey, I., Butler, T., Cofala, J., Collins, W. J., Derwent, R. G., Doherty, R. M., Drevet, J., Eskes, H. J., Fiore, A. M., Gauss, M., Hauglustaine, D. A., Horowitz, L. W., Isaksen, I. S. A., Krol, M. C., Lamarque, J.F., Lawrence, M. G., Montanaro, V., Muller, J.-F., Pitari, G., Prather, M. J., Pyle, J. A., Rast, S., Rodriguez, J. M., Sanderson, M. G., Savage, N. H., Shindell, D. T., Stahan, S. E., Sudo, K., and Szopa, S.: Multimodel ensemble simulations of presentday and near future tropospheric ozone, J. Geophys. Res., 111, D08301, doi:10.1029/2005JD006338, 2006.

Szczodrak, M., Austin, P. H., and Krummel, P. B.: Variability of Optical Depth and Effective Radius in Marine Stratocumulus Clouds, J. Atmos. Sci., 58, 2912-2926, 2001.

Thouret, V., Marenco, A., Logan, J., Nédélec, P., and Grouhel, C.: Comparisons of ozone measurements from the MOZAIC airborne program and the ozone sounding network at eight locations, J. Geophys. Res., 103, 25695-25720, 1998.

Thuiller, G., Hersé, M., Labs, D., Foujols, T., Peetermans, W., Gillotay, D., Simon, P. C., and Mandel. H.: The solar spectral irradiance from 200 to $2400 \mathrm{~nm}$ as measured by the solspec spectrometer from the Atlas and Eureca missions, Solar Phys., 214, $1-22,2003$. 
Tie, X., Madronich, S., Walters, S., Zhang, R., Rasch, P., and Collins, W.: Effect of clouds on photolysis and oxidants in the troposphere, J. Geophys. Res., 108, 4642, doi:10.1029/2003JD003659, 2003.

Twomey, S.: the influence of pollution on the Shortwave Albedo of Clouds, J. Atmos. Sci., 34, 1149-1152, 1977.

van der A, R. J., Allaart, M. A. F., and Eskes, H. J.: Multi sensor reanalysis of total ozone, Atmos. Chem. Phys., 10, 11277-11294, doi:10.5194/acp-10-11277-2010, 2010.

van der Werf, G. R., Randerson, J. T., Giglio, L., Collatz, G. J., Kasibhatla, P. S., and Arellano Jr., A. F.: Interannual variability in global biomass burning emissions from 1997 to 2004, Atmos. Chem. Phys., 6, 3423-3441, doi:10.5194/acp-6-3423-2006, 2006.

van Weele, M. and Duynkerke, P. G.: Effect of Clouds on the Photodissociation of $\mathrm{NO}_{2}$ : Observations and Modelling, J. Atmos. Chem., 16, 231-255, 1993.

von Kuhlmann, R., Lawrence, M. G., Crutzen, P. J., and Rasch, P. J.: A Model for Studies of Tropospheric Ozone and Non-Methane Hydrocarbons: Model description and ozone results, J. Geophys. Res., 108, 4729, doi:10.1029/2002JD002893, 2003.

Vignati, E., Wilson, J., and Stier, P.: M7: An efficient size-resolved aerosol microphysics module for large-scale aerosol transport models, J. Geophys. Res., 109, D22202, doi:10.1029/2003JD004485, 2004.
Voulgarakis, A., Savage, N. H., Wild, O., Carver, G. D., Clemitshaw, K. C., and Pyle, J. A.: Upgrading photolysis in the pTOMCAT CTM: model evaluation and assessment of the role of clouds, Geosci. Model Dev., 2, 59-72, doi:10.5194/gmd-2-592009, 2009a.

Voulgarakis, A., Wild, O., Savage, N. H., Carver, G. D., and Pyle, J. A.: Clouds, photolysis and regional tropospheric ozone budgets, Atmos. Chem. Phys., 9, 8235-8246, doi:10.5194/acp-9-82352009, 2009b.

Wild, O., Zhu, X., and Prather, M. J.: Fast-J: Accurate simulation of in- and below-cloud photolysis in tropospheric chemical models, J. Atmos. Chem., 37, 245-282, 2000.

Williams, J. E. and Van Noije, T. P. C.: On the upgrading of the modified carbon bond mechanism IV for use in global chemistry transport models, Scientific Report WR-2008-02, KNMI, De Bilt, The Netherlands, 2008.

Williams, J. E., Landgraf, J., Bregman, A., and Walter, H. H.: A modified band approach for the accurate calculation of online photolysis rates in stratospheric-tropospheric Chemical Transport Models, Atmos. Chem. Phys., 6, 4137-4161, doi:10.5194/acp-6-4137-2006, 2006.

Zdunkowski, W. G., Welsch, R. M., and Kord, G. J.: An investigation of the structure of typical 2-stream methods for the calculation of solar fluxes and heating rates in clouds, Contrib. Atmos. Phys., 53, 215-238, 1980. 